\title{
MEASUREMENTS ON THE INDEX OF REFRACTION OF AIR FOR WAVE LENGTHS FROM 2218 A TO $9000 \mathrm{~A}$
}

\author{
By W. F. Meggers and C. G. Peters
}

\section{CONTENTS}

I. Introduction.

I. Astronomical observations............................ 698

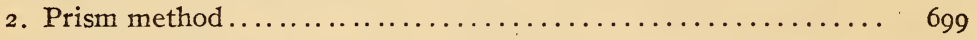

3. Interferometer methods........................... 700

4. Diffraction grating method........................... 702

5. Summary of previous work........................ 703

II. Purpose................................. 706

I. Wave length corrections for temperature and pressure of air..... 706

2. Wave length corrections to vacuum................. 707

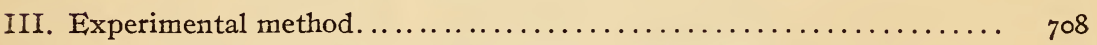

I. Fabry and Perot interferometer for measurement of $n \ldots \ldots \ldots \ldots \quad 708$

IV. Description of apparatus............................. 709

I. General plan.................................. 709

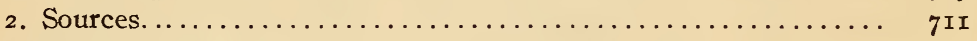

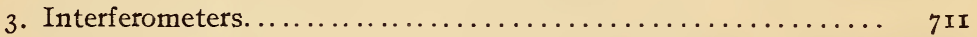

4. Air chamber.................................... $7_{12}$

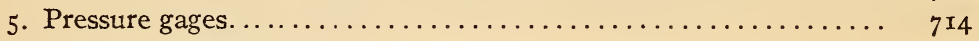

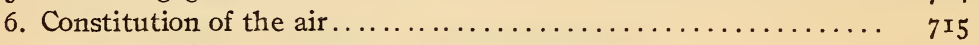

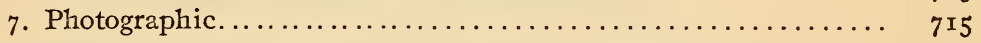

V. Experimental procedure............................. 716

I. Optical adjustments............................ $7_{116}$

2. Temperature regulations......................... $7 \mathrm{I} 6$

3. Pressure observations.......................... $7 \mathrm{I} 6$

4. Photographic exposures.......................... 7 I 7

5. Measurement of ring diameters...................... $7 \mathrm{I} 7$

VI. Reduction of observations......................... 7 I 8



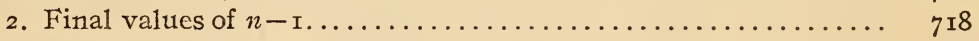

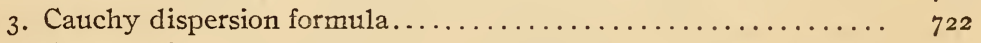

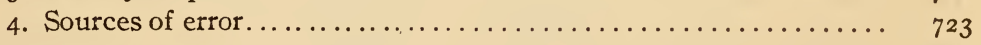

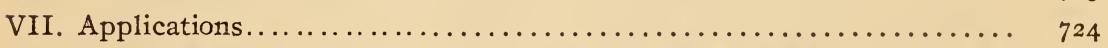

I. Correction of wave-length measurements made in air at other than normal temperatures and pressures............. 724

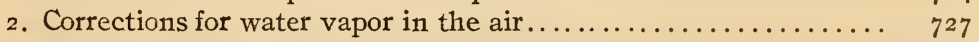

3. Corrections to convert to vacuum values................ 730

4. Astronomical refraction......................... $73^{\circ}$

5. Optical temperature coefficient.................... 734

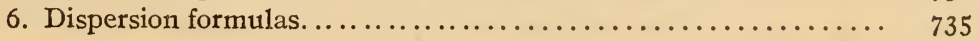

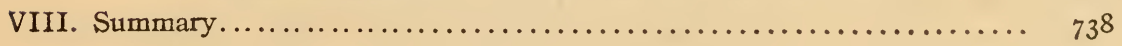




\section{INTRODUCTION}

The optical property of air, by virtue of which the velocity, wave length, and, in general, the direction of light is changed when passing from other merlia into air, has been of practical interest to astronomers and physicists for many centuries. This interest has resulted in a large number of experimental and theoretical researches which have reacted to create a still greater interest in the subject. The majority of researches on the refractivity of air received their inspiration from the desire to correct astronomical observations for the refraction of the earth's atmosphere, and in this connection much work was done to establish the dependence of such corrections on the state of the air as determined by its temperature, pressure, and constitution. Other investigations were later undertaken more especially to test certain theories and laws proposed to represent the relation of refractivity to density and the connection between refractivity and wave length. These are of primary importance to spectroscopists and other physicists. A brief review of the objects, experimental methods, and resuits of these earlier investigations will assist in explaining the purpose of this additional investigation on the index of refraction and dispersion of air described in detail in this paper.

\section{ASTRONOMICAL OBSERVATIONS}

The refractive power of air was first recognized I 900 years ago by Cleomedes, who suspected that it explained the phenomenon of a lunar eclipse when both sun and moon were visible above the earth's horizon. Ptolemy, in the second century, expressed correct ideas of astronomical refraction in his Optics. His attempts to measure this refraction and to find the law connecting incidence and refraction angles were unsuccessful. Astronomical refraction was of no practical importance until the observational instruments and methods were sufficiently refined to measure minutes of arc. In fact, Tycho Brahe, ${ }^{1}$ in the sixteenth century, was the first to measure this refraction successfully and he constructed the first tables of corrections to astronomical observations. After the discovery in the seventeenth century of Snell's law that the index of refraction is a constant ratio of the sines of the incidence and refraction angles, theoretical researches attempted to find the differential equation of the path of light in the earth's atmosphere.

1 Tyco Brahe, Astronomie instauratac Prosymnasmata, Francofurt, 1648 . 
Such an equation appears to have been first derived by Brook Taylor ${ }^{2}$ in I7 5. Then followed the work of Cassini, Bouguer, Bernoulli, Simpson, Bradley, Euler, Lambert, Lagrange, Kramp, and others, climaxed by that of Laplace in r805. Tables constructed on Laplace's formulae were used in astronomy and geodesy for many years. A complete review of these labors of astronomers and physicists upon this complex but interesting subject of astronomical refraction is given in a prize essay by $\mathrm{C}$. Bruhns. ${ }^{3}$

The earliest absolute value of the refractivity of air was determined by Delambre, ${ }^{4}$ whose result was obtained in 1805 from more than 500 observations of the altitudes of circum polar stars. Later values have been deduced from astronomical observations by Bessel, ${ }^{5}$ Gylden, ${ }^{6}$ Fuss, ${ }^{7}$ and others.

\section{PRISM METHOD}

The prism method for measuring the refractive power of gases was first used by Biot and Arago $^{8}$ (I806), who observed with a telescope the apparent change of position of an object seen through a hollow prism filied with air when the density of the air was changed by varying the temperature from $-\mathrm{I} .5$ to $25^{\circ} \mathrm{C}$ and the pressure from 0.005 to $0.8 \mathrm{~m}$ of mercury. From these experiments the absolute index

$$
n=\frac{\sin i}{\sin r}
$$

was obtained for white light and it was concluded that the refractivity of air was proportional to the density. Dulong ${ }^{9}$ (I826) also measured the index of refraction of air for white light by the prism method. Later ( 1893 ) Kayser and Runge ${ }^{10}$ used a copper prism with quartz windows and placed the prism so as to cover part of a concave grating. Lines in the iron spectrum and in the zinc spectrum were photographed, some of the light passing by the prism and the rest passing through the prism containing air under pressures from $\mathrm{I}$ to Io atmospheres. The refractive

2 Brook Taylor, Methodus incrementum, London, I7 15.

${ }^{3}$ C. Bruhns, Die Astronomische Strahlenbrechung, Leipzig; 186r.

4 Delambre, s. Laplace Mecanique celeste, 4; I805.

- Bessel, s. Biot Compt. rend., 40.

- Gylden, Mem. de l'acad. de St. Petersburg, 10, No. I, I866, and 12, No. 4, 1868.

7 Fuss, ibid., 18, No. 4; $x 868$.

8 Biot and Arago, Memoires de l'Institute, 7, p. 301 ; 1806 .

- Dulong, Ann. de Chim. et de Phys. (2), 31, p. $154 ; 1826$.

10 Kayser and Runge, Ann. d. Phys. 50, p. 293; 1393. 
indices for different wave lengths were then determined from the measured shifts of the spectrum lines due to light passing through the prism. Wet air at room temperatures from II to $19^{\circ} \mathrm{C}$ was used for these experiments and the results reduced to represent air at $0^{\circ} \mathrm{C}$ and $760 \mathrm{~mm}$.

A hollow glass prism with air under pressures from I to 5 atmospheres was used by Carnazzi. ${ }^{11}$ Indices of refraction were determined from measurements of the prism angle and the incidence and emergence angles. These results indicated an increase of about $\mathrm{I} 5$ per cent in $\frac{n-\mathrm{I}}{d}$ for this pressure range.

Lang ${ }^{12}$ investigated the dependence of refractive index of air on temperature by observing beams of light reflected from prism faces through windows of a heating apparatus surrounding the prism and noting the deviations for various temperature differences $\left(2.4\right.$ to $95.0^{\circ} \mathrm{C}$ ) between the air inside and outside the apparatus. The observations were represented by the equation $n_{\mathrm{t}}=n_{\mathrm{o}}-0.000000905 t+0.00000000235^{2}$.

\section{INTERFEROMETER METHODS}

The interferometer method for the measurement of refractive indices of gases was first applied by Jamin ${ }^{13}$ (1857). Two Fresnel mirrors were used to make two beams of light, traversing tubes I $\mathrm{m}$ long, interfere and the difference in optical path produced by changing the pressure in one of the tubes was determined with a compensator. Modifications of Jamin's interferometer served later for the work of Ketteler, ${ }^{14}$ Lorenz, ${ }^{15}$ Mascart, ${ }^{16}$ Chappuis and Riviere, ${ }^{17}$ Perreau, ${ }^{18}$ Walker, ${ }^{19}$ Gale, ${ }^{20}$ Magri, ${ }^{21} \mathrm{C}$. and M. Cuthbertson, ${ }^{22}$ Kaiser, ${ }^{22}$ Gruschke, ${ }^{24}$ Ahrberg, ${ }^{25}$ and Koch. ${ }^{28}$ Ketteler measured the absolute index of ordinary air at $0^{\circ} \mathrm{C}$ and 760 $\mathrm{mm}$ for sodium light and indices for lithium and thallium light

\footnotetext{
" Camazzi, Il Nuovo Cimento (6), p. 385; 1897.

12 Von Lang, Pogg. Ann., 153, D. 44 S; 1874.

$18 \mathrm{Jamin,} \mathrm{Ann.} \mathrm{de} \mathrm{Chim.} \mathrm{et} \mathrm{de} \mathrm{Phys.,} \mathrm{49,} \mathrm{p.} 28 z ; 1857$.

1 Ketteler, Pogg. Ann., 12.4, p. 390 ; 1865.

${ }^{16}$ Lorenz, W'icd Ann., 11, p. 70; 1880.

${ }_{16}$ Mascart, Compt. rend., 7S, p. 617; 1874.

${ }^{17}$ Chappuis et Rivicre, Ann. de Chim. et de Phys. (6), 14, p. 5 ; r\&\&s.

10 Perreau, Ann. de Chim. et de Phys. 7, p. 289; 1896.

10 IJ alker, Phit. Trans., 201, p. 435; 1903.

20 Gale, Phys. Rev., 14, p. 1; 1902.

as Magri, Phys, Zeitschr., 6, D. 629; 1905.

IC. and M. Cuthbertson, Proc. Roy. Soc., 83, p. 151; 1910.

n Kaiser, Ann. d. Phys. (4), 13, p. 210 ; 1904.

24 Gruschke, S. A. Jahresber, Schles. Ges. f. Vaterl Kultur, Natura, Sept., 1910.

* A hrberg. Diss. Halle; 1909.

Koch, Nova Acta Soc. Upsal (4), 2; 1909.
} 
relative to that of sodium by observing the differences in pressure required to produce successive coincidences among the fringes due to these different colors. These are the earliest measurements of the dispersive power of air; that is, of refractive indices of air for different wave lengths. Lorenz repeated Ketteler's observations on sodium and lithium light. Mascart divided a beam of white light into two parts, which were sent through two parallel tubes filled with gas and then recombined so as to pass through a spectroscope. When the relative pressures in the two tubes were changed, Talbot bands appeared in the spectrum because of the change in optical path. The index of refraction was determined from a count of the number of bands which passed with a definite change in pressure at points in the spectrum corresponding to four lines in the cadmium arc. Koch used an interference refractometer to measure the indices of air for the residual rays from calcite and gypsum. These waves are longer than those corresponding to an infra-red absorption band due to atmospheric carbon dioxide.

The principle of the Jamin refractometer was used by a number of investigators to find the relation of refractive index to density as affected by pressure or temperature variations.

The experiments of Chappuis and Riviere on air at $2 \mathrm{I}^{\circ} \mathrm{C}$ indicated a proportionality of refractivity to density over a pressure range from o to 20 atmospheres. The same conclusion was arrived at by Perreau who worked with air at $16^{\circ} \mathrm{C}$ up to about 5 atmospheres pressure. Walker measured the refractivity of air under atmospheric pressure at temperatures of 10 to $100^{\circ} \mathrm{C}$ and found the coefficient of index variation with temperature to be about 2 per cent less than the expansion coefficient. Gale's experiments showed that the proportionality of refractivity and density held to o.I per cent for air under pressures from I to 20 atmospheres. Magri investigated the refractivity of air under pressures up to 200 atmospheres and preferred the relation $\frac{n^{2}-I}{\left(n^{2}+I\right) d}=$ Const. The more simple relation $\frac{n-I}{d}=$ Const. was again found by Kaiser for air pressures from o to $\mathrm{I}$ atmosphere.

The Fizeau dilatometer is another type of interferometer which has been used for measurements of the index of refraction of air by Benoit ${ }^{27}$ and by Scheel. ${ }^{28}$ In Benoit's experiments a tripod 
separated two interferometer plates which were illuminated with sodium light to show fringes. The displacement of these fringes when the temperature of the air between the interferometer plates was changed through the range $o$ to $S 0^{\circ} \mathrm{C}$ showed the coefficient of index variation with temperature to be identical with the coefficient of expansion of the gas, that is, 0.00367 . Scheel measured refractive indices for various wave lengths when the air was at temperatures of 16 and $-192^{\circ} \mathrm{C}$.

Rentschler ${ }^{20}$ was the first to make use of the Fabry and Perot type of interferometer for the measurement of refractive indices of a gas for different light waves. Silvered plates separated 9.005 mm were used with a concave grating. The interferometer was illuminated with a quartz mercury lamp; the systems of circular interference fringes produced by different radiations were separated by the diffraction grating and photographed when a vacuum existed between the interferometer plates and also when various pressures of air were present. The air had a temperature of $21 . I^{\circ} \mathrm{C}$, but the fringe shifts from which the indices of refraction were computed were corrected for air at $0^{\circ} \mathrm{C}$ and $760 \mathrm{~mm}$.

The Fabry and Perot interferometer was also used by Miss Matthews ${ }^{30}$ and by Miss Howell. ${ }^{31}$ Miss Matthews undertook to test the relation of refractive index to dẹnsity of air but her results are too meager to warrant any conclusion. Miss Howell used a quartz spectrograph with quartz interferometer plates covered with thin nickel films and measured the index of air for II points between $2652 \mathrm{~A}$ and $667 \mathrm{~S} \mathrm{~A}$.

\section{DIFFRACTION GRATING METHOD}

A diffraction grating in a chamber which could be evacuated was used by Runge ${ }^{32}$ for dispersion measurements in the extreme ultra-violet and very recently by Dickey ${ }^{33}$ for refractive index measurements through a range of spectrum from $2+93 \mathrm{~A}$ to 6 II A. Dickey placed a bell jar with a quartz window over the grating and determined the ratios of iron arc wave lengths in air and vacuum by measuring the change in their diffraction angles when the air was removed from the jar. Values of the index of refraction were deduced for 28 points in the abovementioned spectrum range, the value for each point being determined from the measured shifts of an average of 8 lines in the

I Renischler, Astroph. J1., 99. p. 345: 1908.

Matthews. Jour. Frank. Inst., 1:i, D. 673; 1984

\& Howell, Phy.s. Rev., 6, D. 83, s98s.
28 Runge, Wied Ann.. 55. D. 44: $2 S_{95}$.

¿ Dickey, Astroph. J1., 45. D. IS3; 1917. 
neighborhood. The dispersion was assumed to be linear for this reduction except in the ultra-violet where Kayser and Runge's dispersion formula was used. Great difficulty was encountered with temperature changes in the grating when the space around it was evacuated.

\section{SUMMARY OF PREVIOUS WORK.}

This brief review of the previous work on the index of refraction and dispersion of air may be summarized as follows: Table $I$ is a collection of all the indices of refraction of air which have been given by the observers mentioned above. The last column contains values computed with the aid of a dispersion formula derived from observations which will be described later in this paper.

TABLE 1.- $(\mathrm{n}-1) 10^{7}$

\begin{tabular}{|c|c|c|c|c|c|c|c|c|}
\hline & \multicolumn{8}{|c|}{ Observer and date } \\
\hline & $\begin{array}{c}\text { Delambre, } \\
1805\end{array}$ & $\begin{array}{c}\text { Biot and } \\
\text { Arago, } \\
1806\end{array}$ & $\begin{array}{l}\text { Dulong, } \\
1826\end{array}$ & $\underset{1857}{\text { Jamin, }}$ & $\begin{array}{c}\text { Ketteler, } \\
1865\end{array}$ & $\underset{1874}{\text { Mascart, }}$ & $\begin{array}{l}\text { Lorenz, } \\
1880\end{array}$ & $\begin{array}{c}\text { Bureau } \\
\text { Standards, } \\
1918\end{array}$ \\
\hline $\begin{array}{c}\lambda \\
4800 \\
5085 \\
5345 \\
5378\end{array}$ & $\cdots \cdots$ & & & 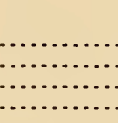 & $\begin{array}{c}2956.69 \\
.6 .6 .\end{array}$ & $\begin{array}{r}2953.0 \\
2944.0 \\
2938.0\end{array}$ & $\begin{array}{l}{ }_{1} \\
\cdots \ldots \ldots \\
\cdots \ldots \ldots\end{array}$ & $\begin{array}{l}2941.1 \\
2933.4 \\
2927.3 \\
2926.6\end{array}$ \\
\hline $\begin{array}{l}5560 \\
5893 \\
6438 \\
6707\end{array}$ & 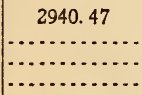 & 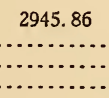 & $\begin{array}{r}2940.0 \\
\cdots \ldots . . .\end{array}$ & $\begin{array}{c}2940.0 \\
\cdots \cdots \cdots \\
\cdots \cdots \cdots\end{array}$ & \begin{tabular}{c}
2947.04 \\
\hdashline 2926.69
\end{tabular} & $\begin{array}{l}2927.0 \\
2921.0\end{array}$ & $\begin{array}{l}2910.8 \\
2900.9\end{array}$ & $\begin{array}{l}2923.2 \\
2917.6 \\
2910.4 \\
2907.5\end{array}$ \\
\hline & $\begin{array}{c}\text { Chappuis } \\
\text { and Riviere, } \\
1888\end{array}$ & $\begin{array}{c}\text { Benoit, } \\
1889\end{array}$ & $\begin{array}{c}\text { Kayser } \\
\text { and Runge, } \\
1893\end{array}$ & $\begin{array}{l}\text { Perreau, } \\
1896\end{array}$ & $\begin{array}{c}\text { Walker, } \\
1903\end{array}$ & $\begin{array}{c}\text { Magri, } \\
1905\end{array}$ & $\begin{array}{c}\text { Scheel, } \\
1907\end{array}$ & $\begin{array}{c}\text { Bureau } \\
\text { Standards, } \\
1918\end{array}$ \\
\hline $\begin{array}{l}2360 \\
2550 \\
2850 \\
2860 \\
3250\end{array}$ & $\cdots$ & & $\begin{array}{l}3216.0 \\
3155.0 \\
3091.0 \\
3085.0 \\
3033.0\end{array}$ & & & & (n. & $\begin{array}{l}3238.2 \\
3171.2 \\
3098.1 \\
3096.2 \\
3036.7\end{array}$ \\
\hline $\begin{array}{l}4200 \\
4358 \\
4430 \\
4677 \\
4710\end{array}$ & $\cdots$ & & $\begin{array}{r}2964.0 \\
2952.0\end{array}$ & $\begin{array}{c}29530 \\
0\end{array}$ & & & $\begin{array}{c}2954.0 \\
2946.0\end{array}$ & $\begin{array}{l}2964.0 \\
2956.9 \\
2954.1 \\
2944.9 \\
2943.9\end{array}$ \\
\hline $\begin{array}{l}4800 \\
4922 \\
5016 \\
5048 \\
5085\end{array}$ & & & & \begin{tabular}{c}
2951.0 \\
$\ldots \ldots \ldots \ldots .$. \\
\hdashline$\ldots \ldots \ldots$ \\
2942.0
\end{tabular} & & & $\begin{array}{c}2937.0 \\
2936.0 \\
2936.0 \\
\ldots \ldots \ldots \ldots\end{array}$ & $\begin{array}{l}2941.1 \\
2937.6 \\
2935.0 \\
2934.2 \\
2933.4\end{array}$ \\
\hline $\begin{array}{l}5378 \\
5460 \\
5630 \\
5780 \\
5893\end{array}$ & \begin{tabular}{c}
$\cdots \ldots \ldots \ldots$ \\
$\cdots \cdots \ldots \ldots \ldots$ \\
\hdashline 2919.0
\end{tabular} & 2922.5 & $\begin{array}{c}\cdots \\
2924.0 \\
\cdots \cdots \cdots \cdots \\
\cdots \cdots \cdots\end{array}$ & 2926.0 & 2928.0 & $\begin{array}{l}2929.0 \\
\cdots \cdots\end{array}$ & $\begin{array}{c}2924.0 \\
2918.0 \\
\ldots \ldots \ldots \ldots\end{array}$ & $\begin{array}{l}2926.6 \\
2925.0 \\
2921.9 \\
2919.3 \\
2917.6\end{array}$ \\
\hline $\begin{array}{l}6152 \\
6438 \\
7056\end{array}$ & $\ldots \ldots$ & & & $\begin{array}{c}3918.0 \\
\ldots \ldots \ldots\end{array}$ & & & $\begin{array}{l}2912.0 \\
2904.0\end{array}$ & $\begin{array}{l}2913.8 \\
2910.4 \\
2904.2\end{array}$ \\
\hline
\end{tabular}


TABLE 1.-(n-1)107-Continued

\begin{tabular}{|c|c|c|c|c|c|c|c|c|}
\hline & $\begin{array}{l}\text { Rentschles, } \\
1908\end{array}$ & $\begin{array}{c}\text { Ahrberg, } \\
1909\end{array}$ & $\begin{array}{c}\text { Koci, } \\
1909\end{array}$ & $\begin{array}{c}\text { Gruschke, } \\
1910\end{array}$ & $\begin{array}{l}\text { Cuthbert- } \\
\text { son, } 1910\end{array}$ & $\begin{array}{c}\text { Howell, } \\
1915\end{array}$ & $\begin{array}{l}\text { Dickey, } \\
1917\end{array}$ & $\begin{array}{c}\text { Bureau } \\
\text { Standards, } \\
1918\end{array}$ \\
\hline \multirow{2}{*}{$\begin{array}{c}1 \\
2493 \\
2567 \\
2614 \\
2652 \\
2665\end{array}$} & & & & & & & $\begin{array}{l}3222.0 \\
3182.0 \\
3159.0\end{array}$ & \multirow{2}{*}{$\begin{array}{l}3189.3 \\
3166.3 \\
3152.9 \\
3142.8 \\
3139.4\end{array}$} \\
\hline & & & & & & 3140.0 & 3138.0 & \\
\hline $\begin{array}{l}2728 \\
2894 \\
2967 \\
3022\end{array}$ & & & & & & \multirow[t]{2}{*}{$\begin{array}{l}3090.2 \\
3073.7 \\
3056.2\end{array}$} & \begin{tabular}{c}
3119.0 \\
\hdashline$\ldots . .$. \\
$\ldots \ldots \ldots$ \\
\end{tabular} & \multirow{2}{*}{$\begin{array}{r}3124.0 \\
3089.7 \\
3076.9 \\
3067.9 \\
3065.3\end{array}$} \\
\hline & & & & & & & 3061.0 & \\
\hline \multirow{2}{*}{$\begin{array}{l}3188 \\
3293 \\
3341 \\
3450 \\
3576\end{array}$} & 3036.0 & & & & & 3043.0 & 3030.0 & \multirow{2}{*}{$\begin{array}{r}3043.2 \\
3031.4 \\
3026.0 \\
3015.0 \\
3003.5\end{array}$} \\
\hline & & & & & & & $\begin{array}{l}301.0 \\
3003.0\end{array}$ & \\
\hline \multirow{3}{*}{$\begin{array}{l}3650 \\
3567 \\
3941 \\
3965 \\
4046\end{array}$} & 2997.0 & & & & & & $\begin{array}{l}2997.0 \\
2981.0\end{array}$ & \multirow{3}{*}{$\begin{array}{l}2997.7 \\
2982.3 \\
2977.8 \\
2975.5 \\
2971.9\end{array}$} \\
\hline & & & & & & 2980.0 & 2977.0 & \\
\hline & 2972.0 & & & & & & & \\
\hline \multirow{2}{*}{$\begin{array}{l}4119 \\
4220 \\
4315 \\
4358 \\
4409\end{array}$} & & & & & & & $\begin{array}{l}2967.0 \\
2965.0 \\
2959.0\end{array}$ & \multirow{2}{*}{$\begin{array}{l}2967.9 \\
2963.1 \\
2958.7 \\
2956.9 \\
2954.9\end{array}$} \\
\hline & 2956.0 & 2957.0 & 2970.9 & & & & 2955.0 & \\
\hline \multirow{2}{*}{$\begin{array}{l}4471 \\
4518 \\
4619 \\
4712 \\
4861\end{array}$} & & & & 2978.0 & & $\begin{array}{l}2955.5 \\
\end{array}$ & 2951.0 & \multirow{2}{*}{$\begin{array}{l}2952.3 \\
2950.9 \\
2947.0 \\
2943.9 \\
2939.3\end{array}$} \\
\hline & & & & 2969.0 & 2951.1 & 2944.0 & 2942.0 & \\
\hline \multirow{3}{*}{$\begin{array}{l}4879 \\
4922 \\
5016 \\
5140 \\
5202\end{array}$} & & & & 2962.0 & & & 2940.0 & \multirow{3}{*}{$\begin{array}{l}2938.7 \\
2937.6 \\
2935.0 \\
2932.1 \\
2930.5\end{array}$} \\
\hline & & & & 2960.0 & & 2935.0 & & \\
\hline & & & & & & & 2926.0 & \\
\hline \multirow{2}{*}{$\begin{array}{l}5270 \\
5328 \\
5406 \\
5460 \\
5616\end{array}$} & & & & & & & $\begin{array}{l}2925.0 \\
2925.0 \\
2922.0\end{array}$ & \multirow{2}{*}{$\begin{array}{l}2928.9 \\
2927.7 \\
2926.1 \\
2925.0 \\
2922.1\end{array}$} \\
\hline & 2930.0 & 2925.0 & 2937.0 & & 2936.0 & & & \\
\hline \multirow{3}{*}{$\begin{array}{l}5769 \\
5780 \\
5790 \\
5876 \\
5893\end{array}$} & 2925.0 & 2919. & & & & & & \multirow{3}{*}{$\begin{array}{l}2919.4 \\
2919.3 \\
2919.2 \\
2917.8 \\
2917.6\end{array}$} \\
\hline & & & & & 2929.8 & 2919.6 & & \\
\hline & & & 2929.8 & 2939.0 & & & & \\
\hline \multirow{2}{*}{$\begin{array}{l}6231 \\
6412 \\
6438 \\
6563 \\
6673\end{array}$} & & & & & & & $\begin{array}{l}2914.0 \\
2910.0\end{array}$ & \multirow{3}{*}{$\begin{array}{l}2912.8 \\
2910.6 \\
2910.4 \\
2908.9 \\
2907.7\end{array}$} \\
\hline & & 2911.0 & & & 2919.2 & & & \\
\hline & & & & & & & & \\
\hline $\begin{array}{l}67094 \\
67094\end{array}$ & & & $\begin{array}{r}2918.5 \\
2880.6\end{array}$ & $\cdots$ & & $\cdots$ & & 2907.5 \\
\hline 86784 & & & 2887.5 & & & & & \\
\hline
\end{tabular}

With a few exceptions the results in Table I are given by the various observers to represent indices of refraction of air at $0^{\circ} \mathrm{C}$ and $760 \mathrm{~mm}$. In most cases, however, the measurements were not made with air actually at $0^{\circ} \mathrm{C}$ and $760 \mathrm{~mm}$, but at various temperatures and pressures and then corrected for the density of the air. In some cases water vapor was present in the air, and a few observers have neglected to state the temperature, 
pressure, or constitution of the air with which they worked. Although these results are for these reasons not strictly comparable, their disagreement on the whole does not appear to be very large, considering the fact that they represent such a large range of experimental methods, apparatus, and observers. Most of the dispersion measurements, however, have been confined to a comparatively small spectral region, and dispersion formulas given to represent these measurements disagree by more than Io per cent of the refractivity $(n-I)$ of air for ultra-violet light.

The Cauchy dispersion formulas given by various observers to represent the refractivity of air $\left(0^{\circ} \mathrm{C}\right.$ and $\left.760 \mathrm{~mm}\right)$ as a function of the wave length in Angstroms are collected here for purposes of comparison, together with some of the values of $(n-I)$ IO $^{7}$ resulting from the formulas.

Dispersion Formulas for Dry Air $\left(0^{\circ} \mathrm{C}\right.$ and $\left.760 \mathrm{~mm}\right)$

Kayser and Runge....(n-I) $\mathrm{IO}^{7}=288 \mathrm{I} .7+\frac{\mathrm{I} 3.16}{\lambda^{2} \times 10^{-8}}+\frac{0.316}{\lambda^{4} \times 10^{-16}}$

Rentschler........... $(n-I) 10^{7}=2903.1+\frac{3.80}{\lambda^{2} \times 10^{-8}}+\frac{1.23}{\lambda^{4} \times 10^{-18}}$

Cuthbertson . . ........ (n-I) $10^{7}=2885.4+\frac{13.38}{\lambda^{2} \times 10^{-8}}+\frac{0.50}{\lambda^{4} \times 10^{-16}}$

Howell.............. $(n-I) 10^{7}=2881.7+\frac{11.83}{\lambda^{2} \times 10^{-8}}+\frac{0.50}{\lambda^{4} \times 10^{-16}}$

Dickey . . . . . . . . (n-I) $10^{7}=2878.12+\frac{1 \mathrm{I} .59}{\lambda^{2} \times 10^{-8}}+\frac{0.55^{I}}{\lambda^{4} \times 10^{-16}}$

Bureau of Standards. . $(n-I) \mathrm{IO}^{7}=2875.66+\frac{\mathrm{I} 3.4 \mathrm{I} 2}{\lambda^{2} \times 10-8}+\frac{0.3777}{\lambda^{4} \times 10^{-16}}$

\begin{tabular}{|c|c|c|c|c|}
\hline Observer & $\lambda 2000$ & $\lambda 4000$ & $\lambda 6000$ & $\lambda 8000$ \\
\hline Kayser and Runge.. & 3408.2 & 2976.3 & 2920.7 & 2903.0 \\
\hline Rentschler................... & 3766.9 & 2974.9 & 2923.1 & 2912.0 \\
\hline Cuthbertson.... & 3532.4 & 2988.6 & 2926.4 & 2907.5 \\
\hline Howell................... & 3464.9 & 2973.6 & 2918.1 & 2901.3 \\
\hline Dickey..................... & 3512.2 & 2972.1 & 2914.6 & 2897.6 \\
\hline Bureau of Standards ....... & 3447.1 & 2973.2 & 2915.8 & 2897.5 \\
\hline
\end{tabular}

Four different expressions have been proposed to represent the relation between the index of refraction of a substance and its density. The earliest one was supported by Newton and indicated $\frac{n^{2}-I}{d}=$ constant. An empirical relation $\frac{n-I}{d}=$ constant was found by Dale and Gladstone ${ }^{34}$ in measurements of refractive indices of liquids at various temperatures. A new relation $\frac{n^{2}-1}{\left(n^{2}+2\right) d}=$ constant, was deduced by Lorenz ${ }^{35}$ from the elastic

अ Dale and Gladsbone, Phil. Trans., 151, p. $317:$ 1863. 35 Lorenz, Wied Anu. 11, p. 70; 1880. 
solid theory and later from the electron theory by Lorentz. ${ }^{30}$ The fourth relation, $\frac{\left(n^{2}+r\right) d}{n^{2}-I}=$ constant, was proposed by Magri ${ }^{37}$ to represent his measurements on air under high pressure. Experiments on gases form the best test of these various relations since the density of gases can be varied more easily than that of solids and liquids. Many of the investigations on air mentioned above were undertaken to find the exact relation of index of refraction to density, but the results are more or less in conflict and point to no definite choice between the different relations proposed. It is evident that this choice depends on extremely accurate measurements, since $n^{2}-I$ differs from an integral multiple of $n-I$ only by a term of the order $(n-I)^{2}$. For air $n-I=0.0003$, approximately, so that $(n-I)^{2}=9 \times 10^{-8}$. It may be that changes in pressures or temperature used to change the density of the air introduce errors in the observations which are much larger than the difference between the relations under test so that as far as can be judged from measurements on air the proposed relationships of index and density are indistinguishable.

\section{PURPOSE}

\section{WAVE LENGTH CORRECTIONS FOR TEMPERATURE AND PRESSURE OF AIR}

The measurements of indices of refraction of air which are described below were inspired by spectroscopic problems connected with the accurate measurement of wave lengths. The fundamental spectroscopic standard has been defined by the International Wave Length Committee as $6438.4696 \mathrm{~A}$ which represents the length of a wave of Cadmium red radiation in dry air at $15^{\circ} \mathrm{C}$ and $76 \mathrm{~cm}$. Other radiations whose wave lengths are determined relative to the primary standard are called secondary standards and a large number of these are required throughout the entire spectral range to facilitate spectroscopic work. When determinations of secondary standards are made in air at temperatures other than $15^{\circ} \mathrm{C}$, and pressures differing from $76 \mathrm{~cm}$. the determinations require corrections which demand a knowledge of the dispersion of the air and the dependence of indices of refraction on density. 


\section{WAVE LENGTH CORRECTIONS TO VACUUM}

Furthermore, it is very desirable to be able to convert wave lengths measured in air to their values in a vacuum. This is especially important for the discussion of mathematical relations among spectral lines in which it is best to use the vacuum values of oscillation frequencies. For this purpose oscillation frequency is defined as the number of waves contained in $\mathrm{I} \mathrm{cm}$ in vacuum; that is, the reciprocal of the wave length in centimeters reduced to its value in vacuum. To reduce the wave length of any line measured in air to its real value in vacuum it is necessary to multiply by the refractive index of air for light of the particular wave length. For air at $15^{\circ} \mathrm{C}$ and $76 \mathrm{~cm}$ this correction amounts to $+2.468 \mathrm{~A}$ for the wave length $9000 \mathrm{~A}$ or -3.05 in the oscillation frequency. At $2000 \mathrm{~A}$ the correction to the wave length is $+0.65 \mathrm{I} \mathrm{A}$ or $-\mathrm{I} 6.28$ to the oscillation frequency. In the early work on spectral series the accuracy of the wave length measurements was not very great and did not warrant correction to vacuum value.

For this reason Kayser and Runge used oscillation frequencies deduced from wave lengths measured in air without reduction to vacuum. Recently, the accuracy of wave length measurements has been increased by the use of the interferometer for wave-length comparisons, and also by the use of large diffraction gratings working with the new system of international standards of wave length derived from interferometer experiments. An accuracy of one part in several millions is now striven for in wave length measurements and to maintain this relative accuracy in the values converted to vacuum it is necessary to know the indices of refraction to two or three units in the seventh decimal place.

This Bureau has been interested in the accurate measurement of wave lengths in spectra of the chemical elements and has had considerable success in extending such measurements out into the infra-red region of the spectrum. Interferometer comparisons have been made in the iron spectrum to $9000 \mathrm{~A}^{38}$ and in the spectra of neon and argon to $8500 \mathrm{~A} .{ }^{38}$ Grating spectra have been photographed and measured in many cases beyond $9000 \mathrm{~A}^{39}$ and waves longer than $10000 \mathrm{~A}$ have been measured in the arc spectra of the ferrous metals. ${ }^{38}$

To correct these measurements to standard atmospheric conditions, and also to change them to vacuum values, requires extensive and accurate data on the refractive and dispersive powers 
of air. The introductory review and summary of such data show that although a large number of researches on the index of refraction of air have been made, employing many different experimental methods, the observations up to the present time have covered a comparatively small spectral region and are often in rather wide disagreement. Most observers have been content with index determinations for one point, or at most only a few points, in the ultra-violet and short wave visible spectral regions, and no values of the index of air have ever been published for waves in the extreme red and adjacent infra-red regions.

The work described in the present paper was first undertaken for the purpose of measuring the indices of refraction of air for red and infra-red light. When this was completed the observations were carried on through the visible spectrum and pushed out into the ultra-violet until practically the entire spectral region which is accessible to ordinary photography was investigated.

\section{EXPERIMENTAL METHOD}

\section{FABRY AND PEROT INTERFEROMETER FOR MEASUREMENT OF n}

For the measurement of absolute indices of refraction_of air, convenience and efficiency together with greatest accuracy recommended the method which makes use of the Fabry and Perot interferometer. This apparatus allows the most satisfactory control of temperature and pressure of the air whose optical properties it is desired to determine. It also permits observations to be recorded simultaneously by photography for a large number of different wave lengths. These advantages determined the use of the Fabry and Perot type of interferometer for the present investigations, and a detailed description of the apparatus will be given in Section IV of this paper.

The experimental method was as follows: Diametric sections of the circular (Haidinger) rings produced by the various rays from a source of light illuminating the parallel plates of the interferometer were photographed, first, when a vacuum existed between the interferometer plates, and then when dry air at atmospheric pressure was present. If the distance between the interferometer plates is $e$, then the number of waves $p$ (order of interference) of length $\lambda$ existing in this distance when air is absent is $p=e / \lambda$. When dry air at atmospheric pressure is present between the plates the wave length $\lambda$ is shortened to $\lambda^{\prime}$, and consequently the number of waves contained in the same distance 
$e$ is increased to $p^{\prime}=e / \lambda^{\prime}$. The total order of interference $p$ at the center of the system of circular fringes in general consists of a whole number $P$ and a fraction $p_{1}$. The fraction $p_{1}$ is determined from measurements of the ring diameters and an approximate value of $P$. If these fractions are obtained for three or more different but known wave lengths, the whole number $P$ and finally the distance $e$ can be found readily and accurately by a method previously described. ${ }^{41}$ Similar procedure is required for the determination of $p^{1}$ and $P^{\prime}$ when air exists between the interferometer plates. When the wave-length values in air were used for finding the order of interference for vacuum between the plates, differences were observed between the computed and measured fractional parts of the order because of the dispersion of the air. These differences were not large enough, however, to introduce any difficulty or ambiguity in the determination of the correct order of interference.

By definition the index of refraction $n$ of air for wave length $\lambda$, is $n=\frac{\text { velocity of light of wave length } \lambda \text { in vacuum }}{\text { velocity of light of wave length } \lambda^{\prime} \text { in air }}$. In either case the velocity is the product of frequency and wave length; and since frequency is assumed to remain constant we may write $n=\frac{\lambda(=\text { wave length in vacuum })}{\left.\lambda^{\prime} \text { (=wave length in air }\right)}$. Now apply the interferometer to the measurement of $n$. When the space between the interferometer plates is exhausted of air, the distance $e$ is found to contain $p$ waves of length $\lambda$. When air at a definite temperature and pressure is present between the plates, $p^{\prime}$ waves of length $\lambda^{\prime}$ are found to be contained in $e$. Since $e$ is a constant distance, $e=p \lambda=p^{\prime} \lambda^{\prime}$, or $\lambda / \lambda^{\prime}=p^{\prime} / p$, and the index of refraction of air under the conditions in which $p^{\prime}$ is observed can be obtained directly from the observed orders of interference $p$ and $p^{\prime}$, that is,

$$
n=\frac{p^{\prime}(=\text { number of waves in } e \text { air })}{p(=\text { number of waves in } e \text { vacuum })} \text {. }
$$

\section{DESCRIPTION OF APPARATUS}

\section{GENERAL PLAN}

The general plan of the apparatus is represented in Figs. I and 2 , which differ only in the dispersive apparatus.

The image of a source of light $O$ is projected with threefold magnification by a quartz lens $L$, upon the interferometer plates

1This Bulletin, 12, p. 198; 1915-1916.

$110990^{\circ}-19-15$ 
$I$, which are inclosed in a cylinder $A$, whose ends are closed with quartz windows. An image of the circular fringes produced by the interferometer is projected upon the slit $S$ of a spectrograph by means of a quartz fluorite achromatic objective $L_{2}$. For most of the work a grating spectrograph was used with the grating mounted in parallel light as shown in Fig. I, where II represents a speculum concave mirror, $G$ the concave grating, and $P$ the photographic plate. The mirror and grating each have a radius of curvature of about $6+0 \mathrm{~cm}$. The grating was ruled by $\mathrm{Dr}$.

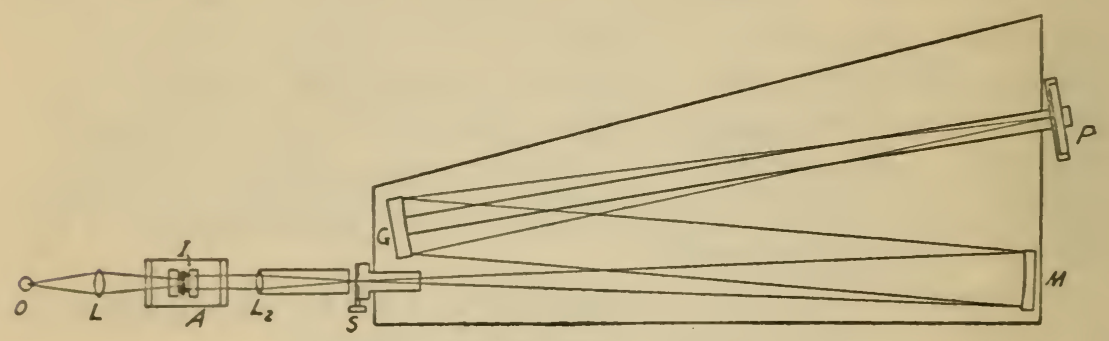

FIG. I.-Grating spectrograph

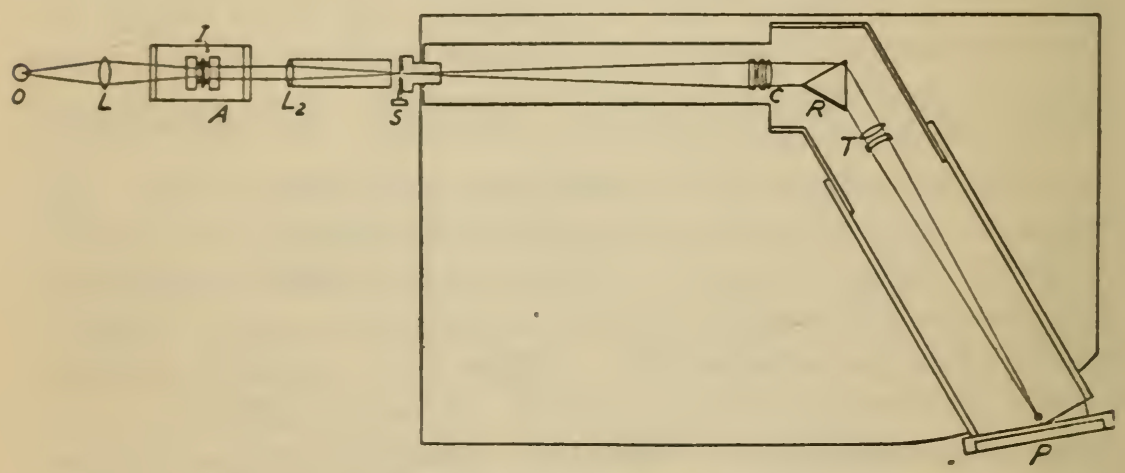

FIG. 2.-Prism spectrograph

Anderson and possesses 39500 lines on a distance of $13.2 \mathrm{~cm}$. The linear dispersion at $P$ with this apparatus is about ro A per millimeter in the spectrum of the first order.

In the region of the spectrum where the waves are shorter than $2800 \mathrm{~A}$ the reflecting power of speculum metal becomes very small and too much light was lost in the reflections from the mirror and grating. For these short waves, therefore, a prism spectograph whose optical parts consist of quartz and rock salt was used to separate the different radiations emanating from the source of light. The prism $R$, Fig. 2, was of rock salt with a $60^{\circ}$ angle and 
3 -inch refracting edge. The collimator $C$ is a quartz rock salt objective and the camera lens $T$ is made of quartz. This spectrograph was designed for the photography of interference fringes in the spectral region 2000-3000 A, and gives a linear dispersion of about I A per millimeter (at $\lambda=2500 \mathrm{~A}$ ) in the focal plane where the photographic plate $P$ is placed.

\section{SOURCES}

The sources of light used in this work were chosen by the following qualifications: (I) The spectra must show a large number of lines of sufficient intensity and regularity of distribution. The lines must be sufficiently sharp or homogeneous to show good interference fringes with comparatively large path differences or orders of interference.

The standard iron arc was used through the range of wave lengths from. $2750 \mathrm{~A}$ to $9000 \mathrm{~A}$ and interferometers were used which made the average order of interference about 20 ooo waves. In the long wave region these observations were supplemented by the use of electrical discharge tubes containing neon and argon. Observations were made with the spectrum of neon between the wave-length limits $5852 \mathrm{~A}$ and $8495 \mathrm{~A}$, and with the spectrum of argon from $6500 \mathrm{~A}$ to $852 \mathrm{I} \mathrm{A}$. The radiations from these gases are quite homogeneous and they were therefore used with a larger order of interference which averaged about 70 ooo waves. In the extreme ultra-violet region the most satisfactory source was found to be a copper arc with a positive carbon electrode above. This spectrum was used for observations in the wave length interval $2200 \mathrm{~A}-3200 \mathrm{~A}$ with orders of interference averaging 16 ooo waves.

\section{INTERFEROMETERS}

The interferometer plates were glass or quartz disks of $42 \mathrm{~mm}$ diameter and 6 or $8 \mathrm{~mm}$ thickness. These plates were thinly covered with metallic films by the method of sputtering from a metallic cathode in a vacuum. Four different pairs of plates were used in all, each pair being used in the spectral region where its metallic films showed their highest reflecting power and the least absorption. In the red and infra-red parts of the spectrum glass plates with thin copper films were used. In the visible spectrum glass plates with silver films were used. For the short visible waves and adjacent ultra-violet quartz plates with nickel films were found most efficient while silicon films on quartz plates were found greatly superior to nickel in the shortest ultra-violet. 
The interferometer plates $I$, Fig. 3 , were held apart and parallel by three invar posts of equal length, held in an invar ring. These invar separators or etalons ranged in length from 2 to $25 \mathrm{~mm}$ depending on the source of light and the spectral region which was being used. The system of plates and etalons was placed in a hollow cylinder ( $5 \mathrm{~cm}$ by $10 \mathrm{~cm}$ ), and held against a flange on one end of this cylinder by screwing a disk $D$ down the other end. This disk had a $2 \mathrm{~cm}$ hole in its center to allow the passage of light through the interferometer. Three small screws in the flange pressed against springs which bore on the interferometer plate facing the flange and permitted the adjustment of the plates to parallelism by varying the pressure on the separating post.

The disk screw $D$ allowed the adaptation of this interferometer mounting to separators or etalons ranging from 2 to $50 \mathrm{~mm}$ in length. After the interferometer plates were adjusted so as to be
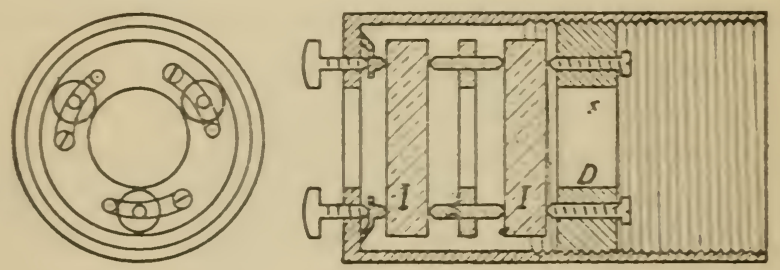

Fig. 3.-Interferometcr

strictly parallel, the entire interferometer mounting was slipped into a closely fitting brass tube $40 \mathrm{~cm}$ long which was surrounded by a bath whose temperature could be regulated at will as described below.

\section{AIR CHAMBER}

In order to secure an accuracy in $n-\mathrm{I}$ of $\mathrm{I}$ in the fourth significant figure, it was necessary to control the temperature of the air under investigation and the interferometer to $0 . \mathrm{I}^{\circ} \mathrm{C}$ and the pressure of the air to $0.3 \mathrm{~mm}$ of mercury. To accomplish this the air chamber A, Fig. 4, was surrounded by a bath of alcohol and water. The liquid was circulated through the tubes $D$ and $E$ by the motor-driven propeller $F$. Cooling was supplied to the liquid by the brine coil $C$ and heat by a 5 -ohm resistance coil $H$, the current in which was regulated by a relay operated by the thermostat $J$. This apparatus was surrounded with ground-cork insulation and mounted in a wooden box. With this arrangement the liquid around $A$ could be held within $0.0 I^{\circ} \mathrm{C}$ of the required 




FIG. 4.-Interferometer in temperature control apparatus 
temperature for any length of time. Temperatures were read with calibrated thermometers Nos. $8290 \mathrm{C}$ and $\mathrm{I}+45+\mathrm{C}$, and a 5 -junction copper-constantin thermocouple calibrated by the heat division of this Bureau.

The chamber $A$ consisted of a thin brass tube $40 \mathrm{~cm}$ long and $5 \mathrm{~cm}$ diameter. The ends were closed with brass rings having $2 \mathrm{~cm}$ openings covered with quartz windows, $\mathrm{W}_{1} \mathrm{~W}_{2}$. The cylinder containing the interferometer $I$ fitted closely within the tube $A$, thus making good metallic contact with the bath. Two brass rings, $M M$, I $\mathrm{cm}$ thick, reduced the radiation from the ends of the tube. A temperature survey was made of $A$ with differential thermocouples when the bath was $20^{\circ}$ above the room temperature. The interferometer plates remained within $0.01^{\circ}$ of constant terperature for one-half hour and differed from the bath temperature by less than $0.02^{\circ} \mathrm{C}$. The plates were $0.02^{\circ}$ warmer than $M$, and $0.7^{\circ}$ above the temperature of the ends of the tube $A$.

\section{DRESSURE GAGES}

The air was exhausted from the cylinder containing the interferometer by means of a Gaede rotary oil pump. An electrical discharge tube inserted between the pump and the cylinder and operated with a ro ooo-volt transformer indicated the degree of exhaustion in the apparatus. For the vacuum observations the apparatus was exhausted of air until the dark space around the electrodes of the electrical discharge tube reached from 5 to ro $\mathrm{mm}$. This low pressure, corresponding to a few hundredths of a millimeter of mercury was maintained throughout the photographic exposure period.

The pressure observations were made after allowing air at atmospheric pressure to filter through calcium chloride and phosphorus pentoxide and fill the apparatus. These atmospheric pressures were usually read from two different barometers used as working standards in this Bureau, and all the necessary corrections were carefully made so that the final pressure observations are probably correct to one or two hundredths of a millimeter. 


\section{CONSTITUTION OF THE AIR}

The barometer readings represent the pressure of dry air whose constituents at the earth's surface are considered to be present in the following volume percentages: ${ }^{42}$

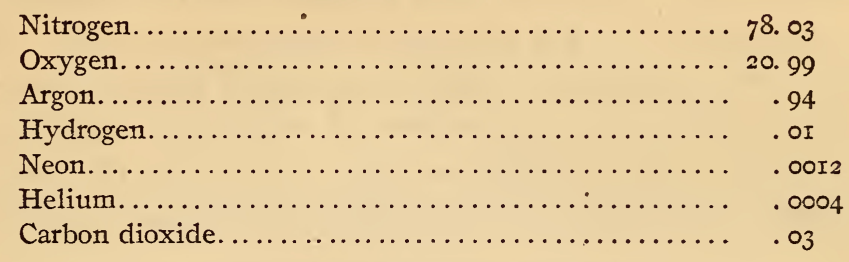

Krypton, Xenon, and Ozone in very small quantities. When the air was removed from the apparatus the spectrum from the electrical discharge tube showed only a trace of hydrogen remaining.

Next to water vapor the atmospheric constituent in which the largest variation occurs is carbon dioxide. The laboratory in which these experiments were conducted was quite well ventilated, so that the volume percentage of carbon dioxide could not have exceeded two times the normal amount.

\section{PHOTOGRAPHIC}

The short wave spectral region from the blue to the extreme ultra-violet was recorded on Graflex photographic plates. For longer waves from green to red in the visible spectrum Seed 27 plates were used after staining with pinacyanol. Overlapping spectra were absorbed by a cell of potassium-bichromate solution. The longest waves in the red and adjacent infra-red were photographed on Seed 27 plates after staining with dicyanin. Here the overlapping spectra were removed by placing a screen of Jena red glass No. 45 2 in front of the slit of the spectrograph.

The photographic plates measured 5 by 8 inches. Each plate therefore covered an interval of $2000 \mathrm{~A}$ with the grating spectrograph and about rooo A with the prism spectrograph in the extreme ultra-violet. The cameras were built so as to allow vertical displacement of the plate holders for a series of exposures on the same plate. 


\section{EXPERIMENTAL PROCEDURE}

1. OPTICAL ADJUSTMENTS

After the interferometer plates were made parallel to each other the interferometer mounting was inserted to the middle of the cylinder surrounded by the constant temperature bath. The box containing this apparatus stood on a tripod fitted with leveling screws and rotating top by means of which the interferometer could be leveled and oriented so that the center of the circular fringe system fell exactly on the center of the spectrograph slit.

\section{TEMPERATURE REGULATIONS}

Spectroscopists are concerned with the index of refraction and dispersion of air at atmospheric pressures and room temperatures since most wave length measurements are made in air under these conditions of pressure and temperature. In these experiments, therefore, extensive observations were made on these optical properties of air at atmospheric pressures and at temperatures of 0 , ${ }^{1} 5$, and $30^{\circ} \mathrm{C}$, which cover the range of ordinary working conditions.

The temperature of the bath surrounding the interferometer was brought to the desired point and maintained by the thermostat control throughout the experiment. This temperature was held for a period of one to two hours before beginning the photographic exposures in order to eliminate temperature gradients and establish a steady state in the interferometer. Cooling or heating effects due to letting air in or exhausting the air from the apparatus were guarded against by allowing 10 to 5 minutes to elapse after each of these operations for a return to the steady state.

\section{PRESSURE OBSERVATIONS}

Each set of photographic exposures was begun with a vacuum between the interferometer plates. The apparatus was washed out with dry air once or twice before the low pressure was maintained for the first exposure. This low pressure, as indicated by the electrical discharge tube, corresponded in general to a pressure of only a few hundredths of a millimeter of mercury. After the observations for vacuum between the interferometer plates were recorded a two-way stopcock cut off the pump and admitted air from the room after being dried by passing through calcium chloride and phosphorus pentoxide. The pressure of this air was read from the barometers described above. When the exposures 
Bulletin Bureau of Standards, Vol. 14

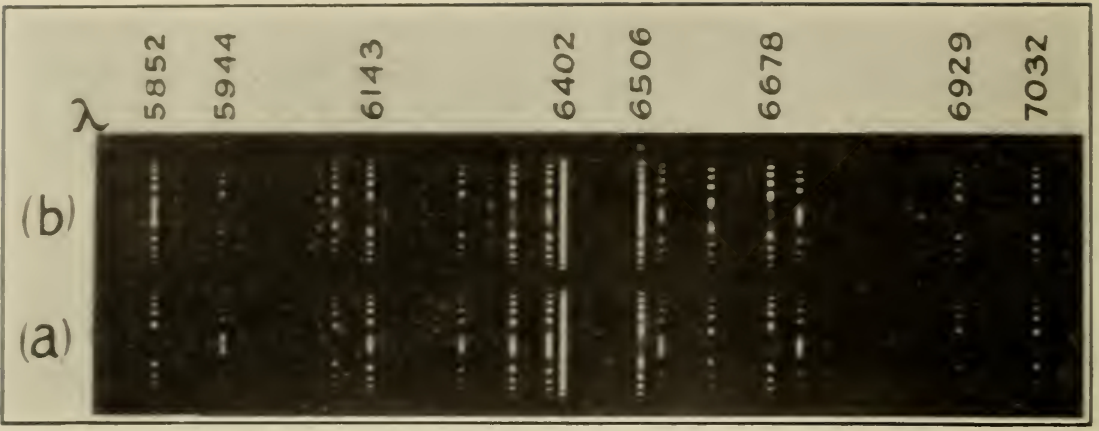

Fig. 5.-Interference fringes in the spectrum of neon

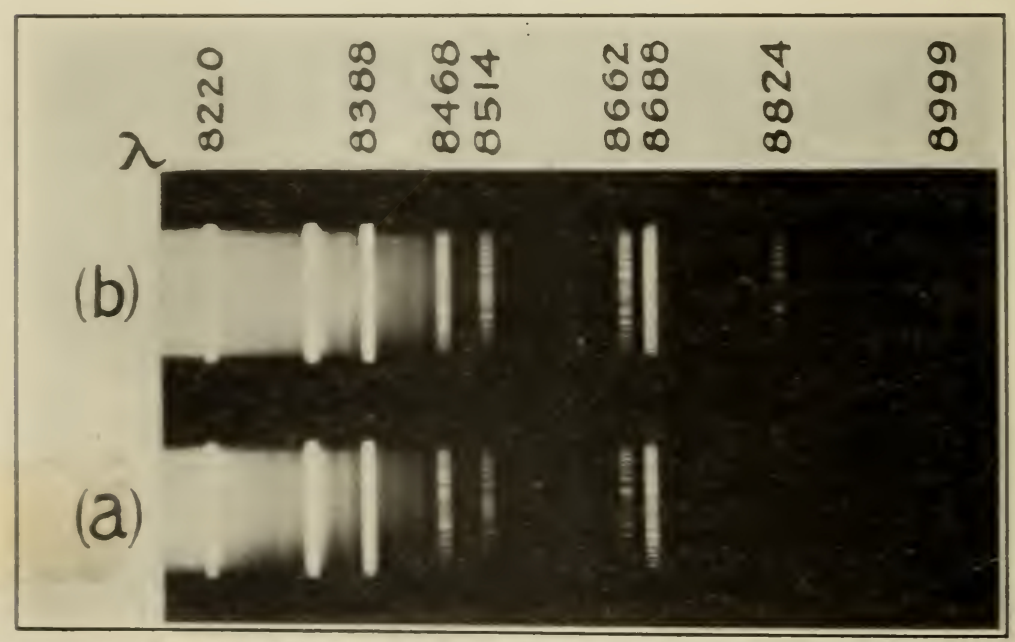

FIG. 6.-Interference fringes in the spectrum of iron 
were longer than about 5 minutes the pressure observations were made before and after and the mean value was used in the density reductions.

\section{PHOTOGRAPHIC EXPOSURES}

In general five photographic exposures were made for each experiment, from which the indices of refraction of air at a definite density could be determined for a certain wave length region. These exposures were made in the following order: (I) Interference rings for vacuum between the interferometer plates; (2) interference rings for dry air between the interferometer plates; (3) interference rings for vacuum between the interferometer plates; (4) interference rings for dry air between the interferometer plates; and (5) gages from which the diameters of the photographed rings could be transformed to their actual size as projected on the slit of the spectrograph. These five exposures were generally made on a 5 by 8 plate, the plate holder being lowered about I. $5 \mathrm{~cm}$ between exposures.

The exposure times in the visible and adjacent ultra-violet spectrum ranged from I to Io minutes. The longest infra-red and shortest ultra-violet waves required exposures of 60 minutes. Spectrum regions were chosen in successive experiments to overlap half of the preceding region.

Several photographs which are typical of those made in this work are reproduced in Figs. 5 and 6 . Fig. 5 shows the yellow and red portion of the spectrum of neon with interference maxima and minima in the spectrum lines. These fringes were produced by an interferometer whose silvered plates were separated 3.75 $\mathrm{mm}$. The first exposure (a) was made after the air was removed, and the second $(b)$ was made with dry air at atmospheric pressure and $15^{\circ} \mathrm{C}$ between the interferometer plates. Fig. 6 shows similar interference phenomena in the infra-red spectrum of iron. These fringes were produced by a ro $\mathrm{mm}$ separation of the interferometer plates with copper films. Wave lengths in dry air at atmospheric pressure and $30^{\circ} \mathrm{C}$ caused $(a)$, and wave lengths in a vacuum gave $(b)$.

\section{MEASUREMENT OF RING DIAMETERS}

The diameters of the interference rings were measured by means of a micrometer screw with a head graduated to $5 \mu$. The diameters of the first three rings were measured for most of the lines: which were used, and for the remainder the first two rings wer' 
measured. In general, these measurements made it possible to compute the orders of interference within a few thousandths of a wave. The fractional parts of the orders of interference agreed so well for the two vacuum and the two air exposures in each experiment that the means of the two sets were used for index computations in every case. No appreciable systematic differences were observed even in cases where the barometric pressure changed slightly between the two air exposures.

\section{REDUCTION OF OBSERVATIONS}

\section{CORRECTIONS TO $760 \mathrm{MM}^{\prime}$}

The index of refraction $n$ of air at a measured density was decluced for a particular wave length $\lambda$ by dividing the number $\left(p^{\prime}=P^{\prime}+p^{\prime}{ }_{1}\right)$ of waves in the double distance $2 e$, separating the interferometer plates when dry air of determined density was present by the number $\left(p=P+p_{1}\right)$ in this same distance when only a negligible quantity of air remained. The number of waves in $2 e$ air was from 5 to 25 greater than the number in $2 e$ vacuum, depending on the size of the etalon and the wave length.

The density of the air experimented upon depended on its temperature $t$ and the barometric pressure $B$ observed at the time of the experiment. The observed barometric pressures ranged between 730 and $760 \mathrm{~mm}$. The final values of $n$ were deduced for diry air under the standard pressure of $760 \mathrm{~mm}$ of $\mathrm{Hg}$, by multiplying the value $n_{\mathrm{s}}$ obtained from the observed barometric pressure $B$ by $\frac{760}{B}$; that is, $n_{780}=n_{\mathrm{B}} \frac{760}{B}$. This assumes that the coefficient of variation of the index of refraction with density is iclentical with the pressure coefficient of volume change at constant temperature. Although considerable disagreement exists among previous observers as to the exact relation between refractivity and density of air, the deviation from exact proportionaity is too small to be appreciable here since the barometric pressures never deviated more than $30 \mathrm{~mm}$ from $760 \mathrm{~mm}$ in these experiments.

\section{FINAL VALUES OF $n-1$}

All of the observations are collected in Table 2. Each value of $n-I$ is the mean of the number of observations indicated in the next column, and this is followed by the correction necessary to place this value on the dispersion curve whose equation was determined from all the observations. 
TABLE 2.-(n-1) $10^{7}$ for Dry Air

\begin{tabular}{|c|c|c|c|c|c|c|c|c|c|c|}
\hline$\lambda \mathbf{A}$ & Source & $\begin{array}{l}\text { Obser- } \\
\text { vations, } \\
0^{\circ} \mathrm{C} \text {, } \\
760 \mathrm{~mm}\end{array}$ & $\begin{array}{l}\text { Num- } \\
\text { ber of } \\
\text { obser- } \\
\text { vations }\end{array}$ & $\begin{array}{c}\text { Com- } \\
\text { puted } \\
\text { minus ob- } \\
\text { served }\end{array}$ & $\begin{array}{l}\text { Obser- } \\
\text { vations, } \\
15^{\circ} \mathrm{C} \text {, } \\
760 \mathrm{~mm}\end{array}$ & $\begin{array}{l}\text { Num- } \\
\text { ber of } \\
\text { obser- } \\
\text { vations }\end{array}$ & $\begin{array}{c}\text { Com- } \\
\text { puted } \\
\text { minus ob } \\
\text { served }\end{array}$ & $\begin{array}{l}\text { Obser- } \\
\text { vations, } \\
30^{\circ} \mathrm{C} \text {, } \\
760 \mathrm{~mm}\end{array}$ & $\begin{array}{l}\text { Num- } \\
\text { ber of } \\
\text { obser- } \\
\text { vations }\end{array}$ & $\begin{array}{c}\text { Com- } \\
\text { puted } \\
\text { minus ob- } \\
\text { served }\end{array}$ \\
\hline \multirow{4}{*}{$\begin{array}{l}2218 \\
2246 \\
2303 \\
2369 \\
2392\end{array}$} & \multirow{4}{*}{$\begin{array}{l}\mathrm{Cu} \\
\mathrm{Cu} \\
\mathrm{Cu} \\
\mathrm{Cu} \\
\mathrm{Cu}\end{array}$} & & & & & & & \multirow{4}{*}{$\begin{array}{l}2982.7 \\
2960.4 \\
2907.5 \\
2879.0 \\
2867.1\end{array}$} & \multirow{4}{*}{$\begin{array}{l}1 \\
2 \\
2 \\
2 \\
2\end{array}$} & \multirow{4}{*}{$\begin{array}{r}-37.3 \\
-26.4 \\
+4.9 \\
+10.9 \\
+15.5\end{array}$} \\
\hline & & & & & & & & & & \\
\hline & & & & & & & & & & \\
\hline & & 3223.4 & 2 & -1.6 & 3050.0 & 2 & -0.5 & & & \\
\hline \multirow{4}{*}{$\begin{array}{l}2406 \\
2441 \\
2492 \\
2618 \\
2739\end{array}$} & \multirow{4}{*}{$\begin{array}{l}\mathrm{Cu} \\
\mathrm{Cu} \\
\mathrm{Cu} \\
\mathrm{Cu} \\
\mathrm{Fe}\end{array}$} & 3222 & 1 & .8 & & & & \multirow{4}{*}{$\begin{array}{l}2869.4 \\
2862.3 \\
2857.7 \\
2833.6 \\
2804.0\end{array}$} & \multirow[t]{4}{*}{2} & \multirow{4}{*}{$\begin{array}{r}+9.0 \\
+5.2 \\
-3.8 \\
-10.0 \\
-4.0\end{array}$} \\
\hline & & & $\begin{array}{l}2 \\
2\end{array}$ & $\begin{array}{l}=1.6 \\
-7.1\end{array}$ & $\begin{array}{l}3046.6 \\
3012.2\end{array}$ & $\begin{array}{l}2 \\
2\end{array}$ & $\begin{array}{r}-14.0 \\
+4.2\end{array}$ & & & \\
\hline & & & 2 & $\begin{array}{r}6.4 \\
+611\end{array}$ & & 2 & & & & \\
\hline & & & & +1 & 29. & 1 & +26 & & & \\
\hline \multirow{3}{*}{$\begin{array}{l}2766 \\
2824 \\
2851 \\
2882 \\
2918\end{array}$} & \multirow{3}{*}{$\begin{array}{l}\mathrm{Cu} \\
\mathrm{Cu} \\
\mathrm{Fe} \\
\mathrm{Cu} \\
\mathrm{Fe}\end{array}$} & 3 & $\frac{1}{2}$ & $\begin{array}{l}-23.4 \\
-3\end{array}$ & 2950.5 & 2 & $\begin{array}{l}2.2 \\
=42\end{array}$ & \multirow{3}{*}{$\begin{array}{l}2787.1 \\
2779.3 \\
2768.3 \\
2774.1 \\
2752.1\end{array}$} & & \multirow{3}{*}{$\begin{array}{r}+7.4 \\
+4.8 \\
+11.3 \\
+\quad .6 \\
+17.1\end{array}$} \\
\hline & & & $\begin{array}{l}2 \\
1\end{array}$ & $\mp 2.3$ & & 2 & & & & \\
\hline & & & $\begin{array}{l}1 \\
1\end{array}$ & $\begin{array}{r}+11.3 \\
+5.4\end{array}$ & $\begin{array}{l}2921.0 \\
2912.3\end{array}$ & $\begin{array}{l}2 \\
1\end{array}$ & $\begin{array}{r}+4.9 \\
+7.3\end{array}$ & & & \\
\hline \multirow{4}{*}{$\begin{array}{l}2961 \\
2987 \\
2997 \\
3010 \\
3036\end{array}$} & \multirow{4}{*}{$\begin{array}{l}\mathrm{Cu} \\
\mathrm{Fe} \\
\mathrm{Cu} \\
\mathrm{Cu} \\
\mathrm{Cu}\end{array}$} & 3078.3 & 2 & -.6 & 0 & 2 & -1.2 & \multirow{4}{*}{$\begin{array}{l}2746.2 \\
274.8 \\
2742.6 \\
2751.9 \\
2745.0\end{array}$} & \multirow{4}{*}{$\begin{array}{l}1 \\
2 \\
2 \\
2\end{array}$} & \multirow{4}{*}{$\begin{array}{r}+16.6 \\
+14.4 \\
+15.3 \\
+4.4 \\
+7.8\end{array}$} \\
\hline & & & 1 & -.3 & & 1 & -9.2 & & & \\
\hline & & & $\frac{2}{2}$ & $\begin{array}{l}=2.5 \\
-8.6\end{array}$ & & ${ }_{1}^{1}$ & $\begin{array}{l}-8 . \\
+10 .\end{array}$ & & & \\
\hline & & 308 & 1 & -18.5 & $\begin{array}{l}2908.8 \\
2908.2\end{array}$ & 1 & -6.6 & & & \\
\hline & Fe & & & & 2910.5 & 1 & -1.7 & & & \\
\hline $\begin{array}{l}3063 \\
3075\end{array}$ & $\stackrel{C}{F}$ & 3066.1 & 2 & -4.6 & & 1 & -3.5 & & 1 & $\mp$ \\
\hline $\begin{array}{l}3116 \\
3175\end{array}$ & $\begin{array}{l}\mathrm{Fe} \\
\mathrm{Fe}\end{array}$ & & $\begin{array}{l}1 \\
1\end{array}$ & $\begin{array}{r}+5.0 \\
+11.5\end{array}$ & $\begin{array}{l}2889.8 \\
2894.0\end{array}$ & 1 & $\begin{array}{l}+.8 \\
-10.7\end{array}$ & & 1 & $\begin{array}{r}3.1 \\
+16.6\end{array}$ \\
\hline & F & 3038. & 1 & + & & 1 & -5.2 & & 1 & + \\
\hline & & & 1 & + & & 1 & -1.1 & & 1 & - \\
\hline & & & 1 & & & 1 & \pm 7 & & 1 & - \\
\hline 348 & F & 3004 & 1 & $\begin{array}{l}7.0 \\
+7.2\end{array}$ & 20 & 1 & $=5.1$ & & 1 & \\
\hline 35 & $\mathrm{Fe}$ & & 1 & -.9 & & 1 & -8.5 & & 1 & -10 \\
\hline & & & 1 & + & & 1 & -2 & & 1 & \\
\hline & & & & + & & 1 & -3 & & & \\
\hline 3701 & $\mathrm{Fe}$ & 2996. & 1 & -2.7 & 2834.4 & 1 & $\begin{array}{l}+1.9 \\
+\quad .9\end{array}$ & 2679.0 & 1 & $\begin{array}{r}-3.8 \\
+13.9\end{array}$ \\
\hline 37 & $\mathrm{Fe}$ & 2988.0 & 4 & +1.9 & 28 & 4 & -.2 & 2688.0 & 4 & +1.6 \\
\hline & $\frac{F}{F}$ & & & & & 2 & & & & \\
\hline & $\bar{F}$ & 2977.5 & 1 & +6.3 & 2829.2 & 4 & -3.4 & & 3 & -4.9 \\
\hline 384 & & & & & & & & & 1 & \\
\hline 3865 & $\mathrm{Fe}$ & & & & 2826.1 & 2 & -1.6 & & 1 & \\
\hline & $\begin{array}{l}\mathrm{Fe} \\
\mathrm{Ee}\end{array}$ & & $\begin{array}{l}3 \\
1\end{array}$ & $\begin{array}{l}+.88 \\
-13.5\end{array}$ & 2821.6 & 3 & +.6 & & 1 & + \\
\hline & $\begin{array}{l}F \\
F\end{array}$ & 297 & 3 & & & 2 & $\begin{array}{r}+5.8 \\
-1.0\end{array}$ & & 3 & \\
\hline $39 \%$ & & & 1 & +9. & 2815 & & & & 1 & -4.0 \\
\hline & $\mathrm{Fe}$ & 29 & 3 & & & 3 & -3.4 & 2677.3 & 3 & -.2 \\
\hline & $\begin{array}{l}\mathrm{Fe} \\
\mathrm{Fe}\end{array}$ & $\begin{array}{l}2971 . \\
2070\end{array}$ & 4 & \pm 1.4 & & 4 & +.3 & & 4 & +56 \\
\hline & & & & & & & & & & \\
\hline & Fe & $\begin{array}{l}2906.6 \\
2973.4\end{array}$ & $\begin{array}{l}3 \\
4\end{array}$ & $\begin{array}{r} \pm 2.5 \\
-5.5\end{array}$ & & 3 & $\begin{array}{r}+2.9 \\
+2.0\end{array}$ & 2676.0 & 3 & -4.0 \\
\hline & $\pi e$ & & & . & & 4 & +2.1 & 2666.8 & 4 & +2.9 \\
\hline 421 & $\mathrm{Fe}$ & 2970.0 & $\ddot{i}$ & -6.6 & 2808.1 & 1 & -1.1 & 2608.7 & $\dddot{i}$ & -1.6 \\
\hline 421 & $\begin{array}{l}\mathrm{Fe} \\
\mathrm{Fe}\end{array}$ & $\begin{array}{r}2963.6 \\
\end{array}$ & 3 & -.4 & $\begin{array}{l}2805.3 \\
2807.1\end{array}$ & 3 & $\begin{array}{r}+1.6 \\
\pm 11\end{array}$ & 2659.7 & 3 & -2.7 \\
\hline & $\mathrm{Fe}$ & & $\dddot{3}$ & -4 & & 3 & 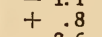 & & 3 & -2.3 \\
\hline 431 & & & $\frac{1}{3}$ & -2.2 & 2800.4 & $\begin{array}{l}3 \\
5\end{array}$ & $\begin{array}{r}-3.6 \\
+2.3\end{array}$ & 2663.8 & $\begin{array}{l}1 \\
3\end{array}$ & $\begin{array}{r}+13.5 \\
-\quad .8\end{array}$ \\
\hline 435 & $\mathrm{Fe}$ & 2967. & 1 & -10.5 & 2805.9 & 1 & & & 1 & \\
\hline 40 & $\begin{array}{l}\mathrm{Fe} \\
\mathrm{Fe}\end{array}$ & & 3 & & & 3 & +21 & 2663.9 & 3 & \\
\hline $\begin{array}{l}442 \\
442\end{array}$ & $\begin{array}{l}\mathrm{Fe} \\
\mathrm{Fe}\end{array}$ & 2954.7 & 3 & -.6 & & 2 & it & 2664.4 & 3 & -5.5 \\
\hline
\end{tabular}


TABLE 2-Continued

\begin{tabular}{|c|c|c|c|c|c|c|c|c|c|c|}
\hline$\lambda \mathbf{A}$ & Source & $\begin{array}{l}\text { Obser- } \\
\text { vations, } \\
0^{\circ} \mathrm{C}, \\
760 \mathrm{~mm}\end{array}$ & $\begin{array}{l}\text { Num- } \\
\text { ber of } \\
\text { obser- } \\
\text { vations }\end{array}$ & $\begin{array}{c}\text { Com- } \\
\text { puted } \\
\text { minus ob- } \\
\text { served }\end{array}$ & $\begin{array}{l}\text { Obser- } \\
\text { vations, } \\
11^{\circ} \mathrm{C} \text {, } \\
760 \mathrm{~mm}\end{array}$ & $\begin{array}{l}\text { Num- } \\
\text { ber of } \\
\text { obser- } \\
\text { vations }\end{array}$ & $\begin{array}{l}\text { Com- } \\
\text { puted } \\
\text { mlnus ob- } \\
\text { served }\end{array}$ & $\begin{array}{l}\text { Obser- } \\
\text { vattons, } \\
30^{\circ} \mathrm{C} \text {, } \\
760 \mathrm{~mm}\end{array}$ & $\begin{array}{l}\text { Num- } \\
\text { ber of } \\
\text { obser- } \\
\text { vations }\end{array}$ & $\begin{array}{c}\text { Com- } \\
\text { puted } \\
\text { minns ob- } \\
\text { served }\end{array}$ \\
\hline \multirow{4}{*}{$\begin{array}{l}4484 \\
4494 \\
4531 \\
4547 \\
4592\end{array}$} & \multirow{4}{*}{$\begin{array}{l}\mathrm{Fe} \\
\mathrm{Fe} \\
\mathrm{Fe} \\
\mathrm{Fe}_{0} \\
\mathrm{Fe}_{\mathrm{e}}\end{array}$} & 2950.9 & 3 & +0.9 & & & & & & \\
\hline & & & & & \multirow{3}{*}{$\begin{array}{l}2796.4 \\
2794.4 \\
2789.0 \\
2791.9\end{array}$} & \multirow{3}{*}{$\begin{array}{l}5 \\
2 \\
3 \\
3\end{array}$} & \multirow{3}{*}{$\begin{array}{r}0.4 \\
+\quad .3 \\
+5.2 \\
+\quad .2\end{array}$} & 2656. 2 & 3 & +0.5 \\
\hline & & $\begin{array}{l}2947.3 \\
2943.4\end{array}$ & $\begin{array}{l}3 \\
3\end{array}$ & $\begin{array}{r}1.1 \\
+44\end{array}$ & & & & 2655.0 & $\dddot{3}$ & $\therefore$ \\
\hline & & & & & & & & 2654.9 & 3 & -1.2 \\
\hline \multirow{7}{*}{$\begin{array}{l}4602 \\
4647 \\
4691 \\
4736 \\
4789 \\
4859 \\
4903 \\
4966 \\
5001 \\
5012\end{array}$} & \multirow{7}{*}{$\begin{array}{l}\mathrm{Fe} \\
\mathrm{Fe} \\
\mathrm{Fe} \\
\mathrm{Fe} \\
\mathrm{Fe} \\
\mathrm{Fe} \\
\mathrm{Fe} \\
\mathrm{Fe} \\
\mathrm{Fe} \\
\mathrm{Fe}\end{array}$} & 2946.3 & 3 & -.4 & \multirow{7}{*}{$\begin{array}{l}2790.7 \\
2787.8 \\
2785.2 \\
2789.2 \\
2778.4 \\
2787.6 \\
2783.2 \\
2789.1\end{array}$} & \multirow[t]{7}{*}{2} & \multirow{2}{*}{$\begin{array}{r}+.6 \\
+3.1\end{array}$} & & & \multirow{7}{*}{$\begin{array}{r}2.8 \\
+1.2 \\
+4.0 \\
+\quad .6 \\
=1.9 \\
=2.3 \\
+\quad .8\end{array}$} \\
\hline & & $29+3.0$ & 3 & +1.4 & & & & $\begin{array}{l}2554.9 \\
2649.7\end{array}$ & $\begin{array}{l}3 \\
3\end{array}$ & \\
\hline & & 2938. 9 & 3 & +4.1 & & & $-\quad .9$ & 2653.6 & 3 & \\
\hline & & 2935.7 & 3 & +5.6 & & & -1.7 & & 3 & \\
\hline & & 2938. 0 & 3 & +1.3 & & & -2.8 & 5 & 3 & \\
\hline & & 293 & 3 & $\begin{array}{r}+.4 \\
+30\end{array}$ & & & \pm .5 & & 3 & \\
\hline & & 2935.5 & 3 & -.2 & & & \multirow{2}{*}{-2.1} & 2642.0 & 3 & \\
\hline \multirow{4}{*}{$\begin{array}{l}5051 \\
5110 \\
5167 \\
5171 \\
5232\end{array}$} & & 29 & 3 & -1.9 & 2783.0 & & & 26420 & & \\
\hline & $\mathrm{Fe}$ & & 5 & +2 & \multirow{3}{*}{$\begin{array}{l}2764.0 \\
2784.3 \\
2779.3 \\
2776.9 \\
2779.2\end{array}$} & \multirow{3}{*}{$\begin{array}{l}2 \\
5 \\
2 \\
5\end{array}$} & \multirow{3}{*}{$\begin{array}{r}+16.0 \\
-5.6 \\
-1.8 \\
+\quad .5 \\
-3.1\end{array}$} & & 5 & $=3.0$ \\
\hline & $\begin{array}{l}F e \\
F e\end{array}$ & 2930. & $\begin{array}{l}3 \\
2\end{array}$ & $\begin{array}{r}+4.4 \\
+\quad 2\end{array}$ & & & & & $\begin{array}{l}3 \\
2\end{array}$ & +.2 \\
\hline & & 2934.2 & 5 & -4.4 & & & & 2636.4 & 5 & $\begin{array}{l}+1.8 \\
+1.5\end{array}$ \\
\hline \multirow{4}{*}{$\begin{array}{l}5266 \\
5324 \\
5397 \\
5455 \\
5506\end{array}$} & $\mathrm{Fe}$ & 2935. & 2 & -9.8 & \multirow{4}{*}{$\begin{array}{l}2775.9 \\
2771.9 \\
2773.4 \\
2772.8\end{array}$} & & & 5 & 2 & +.7 \\
\hline & $\begin{array}{l}\mathrm{Fe} \\
\mathrm{Fe}\end{array}$ & & $\frac{2}{2}$ & $\begin{array}{l}-8.4 \\
-3.9\end{array}$ & & $\begin{array}{l}2 \\
2\end{array}$ & $\begin{array}{r}-1.6 \\
+9.9\end{array}$ & & $\frac{2}{2}$ & $\begin{array}{r}+5.4 \\
\pm 1.3\end{array}$ \\
\hline & $\mathrm{Fe}$ & & 2 & $+\quad .6$ & & 2 & \pm 1.7 & & $\begin{array}{l}2 \\
2\end{array}$ & $=1.3$ \\
\hline & & 2922.6 & 2 & +1.4 & & 2 & -2.0 & 2636.0 & 2 & -3.1 \\
\hline $\begin{array}{l}5569 \\
5624\end{array}$ & $\mathrm{Fe}$ & $\begin{array}{r}2925.9 \\
2931.3\end{array}$ & 2 & $\begin{array}{l}3.0 \\
=9.5\end{array}$ & 2779.0 & $\frac{2}{2}$ & $=9.2$ & 3 & 2 & +.5 \\
\hline $\begin{array}{l}5624 \\
5658\end{array}$ & $\mathrm{Fe}$ & $\begin{array}{l}29 \\
29\end{array}$ & 2 & $\begin{array}{l}-9.5 \\
-2.5\end{array}$ & & $\begin{array}{l}2 \\
2\end{array}$ & $\begin{array}{l}=7.3 \\
-2.5\end{array}$ & & $\begin{array}{l}2 \\
2\end{array}$ & $\begin{array}{l}-1.6 \\
+\quad .5\end{array}$ \\
\hline $\begin{array}{l}5709 \\
5763\end{array}$ & $\begin{array}{l}\mathrm{Fe} \\
\mathrm{Fe}\end{array}$ & 2925.1 & $\begin{array}{l}2 \\
2\end{array}$ & $\begin{array}{l}-11.1 \\
-5.6\end{array}$ & 2767.5 & $\frac{2}{2}$ & $\begin{array}{r}-3.8 \\
-\quad .9\end{array}$ & $\begin{array}{l}2628.2 \\
2624.1\end{array}$ & $\begin{array}{l}2 \\
2\end{array}$ & $\begin{array}{l}+1.6 \\
+4.9\end{array}$ \\
\hline 585 & $\mathrm{Nc}$ & & & & 2769 & 4 & -3.9 & 26 & 3 & -1.9 \\
\hline & $\begin{array}{l}\mathrm{Ne} \\
\mathrm{Fe}\end{array}$ & 2924.6 & 2 & -7.1 & & $\begin{array}{l}4 \\
2\end{array}$ & $\begin{array}{l}-3 \\
-2\end{array}$ & & 3 & \\
\hline & $\begin{array}{l}\text { Fe } \\
\text { Ne }\end{array}$ & & & & & 2 & -2.9 & $\begin{array}{l}2638.8 \\
2620\end{array}$ & 2 & -12.2 \\
\hline & & 2928.5 & 2 & -12.8 & 2765.8 & 2 & -2.6 & & & \\
\hline $\begin{array}{l}6029 \\
6065\end{array}$ & $\begin{array}{l}\mathrm{Fe} \\
\mathrm{Fe}\end{array}$ & 2918.9 & 2 & -40 & 500.0 & & & 2634.1 & 1 & -8.8 \\
\hline $60^{\circ 4}$ & Ne & & & -4.0 & 276 & 2 & $=4.5$ & & 2 & \\
\hline 6096 & $\mathrm{Ne}$ & & & & 2763.6 & 5 & -1.5 & 2626.1 & 3 & -1.6 \\
\hline $\begin{array}{l}6136 \\
6143\end{array}$ & $\begin{array}{l}\mathrm{Fe} \\
\mathrm{Ne}\end{array}$ & 2915. 2 & 2 & -1.2 & $\begin{array}{l}2766.0 \\
2764\end{array}$ & 2 & -4.4 & 2623.4 & 2 & +.7 \\
\hline 61 & $\mathrm{Ne}$ & $x 0133$ & $?$ & & & 5 & $=\quad .8$ & & 3 & $\begin{array}{l}=-1.9 \\
-2.8\end{array}$ \\
\hline 621 & re & 2913.3 & 2 & .2 & 6767.0 & $\begin{array}{l}3 \\
5\end{array}$ & $\begin{array}{l}-\quad 6.1 \\
-\quad .9\end{array}$ & $\begin{array}{l}2620.7 \\
2625.7\end{array}$ & $\begin{array}{l}2 \\
3\end{array}$ & $\begin{array}{l} \pm 2.7 \\
-2.6\end{array}$ \\
\hline $\begin{array}{l}6219 \\
6230\end{array}$ & $\begin{array}{l}\mathrm{Fe} \\
\mathrm{Fe}\end{array}$ & & & & $\begin{array}{r}2762.9 \\
2767\end{array}$ & 1 & -2. & & & \\
\hline & Fe & & & & & 2 & -7.1 & & & \\
\hline $\begin{array}{l}625 \\
626\end{array}$ & $\begin{array}{l}\mathrm{Fe} \\
\mathrm{Ne}\end{array}$ & 2912.6 & 2 & -.2 & 2764.9 & $\begin{array}{l}2 \\
6\end{array}$ & $\begin{array}{l}=.5 \\
=5.0\end{array}$ & $\begin{array}{l}2620.7 \\
2624.8\end{array}$ & $\begin{array}{l}2 \\
3\end{array}$ & \pm 2.0 \\
\hline 6297 & $\mathrm{Fe}$ & 2904.0 & 2 & +7.9 & 2746.5 & 2 & +13 & & & \\
\hline & Ne & & & & & 6 & \pm & 2623.8 & 3 & -1.6 \\
\hline & $\begin{array}{l}\text { Ne } \\
\mathrm{Fe}\end{array}$ & 2910.6 & 2 & +.8 & 2758.1 & $\begin{array}{l}7 \\
2\end{array}$ & $\begin{array}{r}2.3 \\
+1.1\end{array}$ & $\begin{array}{l}2624.7 \\
2621.0\end{array}$ & $\begin{array}{l}3 \\
2\end{array}$ & $\begin{array}{r}2.8 \\
+\quad .9\end{array}$ \\
\hline $\begin{array}{l}6382 \\
6393\end{array}$ & Ne & & & & 2763.6 & 7 & & & 3 & \\
\hline & $\mathrm{F}$ & 2911.1 & 2 & & & $\begin{array}{l}7 \\
3\end{array}$ & $\begin{array}{l}-5.1 \\
-6.6\end{array}$ & 2620.3 & 4 & $\begin{array}{l}+.9 \\
+.9 .\end{array}$ \\
\hline & $\mathbf{F}$ & 2910.4 & 4 & -.2 & 2761.4 & $\begin{array}{l}6 \\
7\end{array}$ & $\begin{array}{l}=4.7 \\
-3.2\end{array}$ & $\begin{array}{l}2623.9 \\
2615.3\end{array}$ & $\begin{array}{l}3 \\
4\end{array}$ & $\begin{array}{r}-2.8 \\
+5.5\end{array}$ \\
\hline 6462 & $\mathrm{Fe}$ & 2905.5 & 2 & +4.5 & 276 & 1 & -11.0 & & 2 & \\
\hline & $N$ & & & & & $\begin{array}{l}6 \\
6\end{array}$ & $\begin{array}{l}=4.2 \\
=4.7\end{array}$ & & $\frac{2}{3}$ & $\begin{array}{l}+2.2 \\
-1.4\end{array}$ \\
\hline ES46 & $\mathrm{Fe}$ & 2909.0 & 7 & +.1 & 2761.0 & 7 & $\begin{array}{l}=3.8 \\
-4.0\end{array}$ & 2619.8 & $\begin{array}{l}3 \\
4\end{array}$ & 2.8 \\
\hline
\end{tabular}


TABLE 2-Continued

\begin{tabular}{|c|c|c|c|c|c|c|c|c|c|c|}
\hline$\lambda \mathbf{A}$ & Source & $\begin{array}{c}\text { Obser- } \\
\text { vations, } \\
0^{\circ} \mathrm{C} \text {, } \\
760 \mathrm{~mm}\end{array}$ & $\begin{array}{l}\text { Num- } \\
\text { ber of } \\
\text { obser- } \\
\text { vations }\end{array}$ & $\begin{array}{c}\text { Com- } \\
\text { puted } \\
\text { minus ob- } \\
\text { served }\end{array}$ & $\begin{array}{l}\text { Obser- } \\
\text { vations, } \\
15^{\circ} \mathrm{C} \text {, } \\
760 \mathrm{~mm}\end{array}$ & $\begin{array}{l}\text { Num- } \\
\text { ber of } \\
\text { obser- } \\
\text { vations }\end{array}$ & $\begin{array}{c}\text { Com- } \\
\text { puted } \\
\text { minus ob- } \\
\text { served }\end{array}$ & $\begin{array}{c}\text { Obser- } \\
\text { vations, } \\
30^{\circ} \mathrm{C} \text {, } \\
760 \mathrm{~mm}\end{array}$ & $\begin{array}{l}\text { Num- } \\
\text { ber of } \\
\text { obser- } \\
\text { vations }\end{array}$ & $\begin{array}{c}\text { Com- } \\
\text { puted } \\
\text { minus ob- } \\
\text { served }\end{array}$ \\
\hline $\begin{array}{l}6553 \\
6598 \\
6609 \\
6663 \\
6678\end{array}$ & $\begin{array}{l}\mathrm{Fe} \\
\mathrm{Fe} \\
\mathrm{Ne}\end{array}$ & $\begin{array}{l}2915.9 \\
2913.6\end{array}$ & $\begin{array}{l}2 \\
2\end{array}$ & $\begin{array}{r}-8.6 \\
-5.8\end{array}$ & $\begin{array}{l}2760.2 \\
2760.2 \\
2762.8 \\
2759.6 \\
2754.6\end{array}$ & $\begin{array}{l}1 \\
7 \\
1 \\
3 \\
7\end{array}$ & $\begin{array}{l}-3.3 \\
=3.6 \\
=6.4 \\
=3.7 \\
+1.2\end{array}$ & $\begin{array}{l}2619.6 \\
2612.5 \\
2627.4 \\
\ldots \ldots \ldots\end{array}$ & $\begin{array}{l}3 \\
2 \\
2\end{array}$ & $\begin{array}{r}+0.3 \\
+\quad 6.6 \\
-8.8 \\
\end{array}$ \\
\hline $\begin{array}{l}6678 \\
6717 \\
6750 \\
6752 \\
6841\end{array}$ & $\begin{array}{l}\mathrm{Fe} \\
\mathrm{Ne} \\
\mathrm{Fe} \\
\mathrm{A} \\
\mathrm{Fe}\end{array}$ & $\begin{array}{r}2907.5 \\
2901.9 \\
2907.0\end{array}$ & $\ddot{2}$ & $\begin{array}{l}+.1 \\
-5.1 \\
\cdots .1 .0\end{array}$ & $\begin{array}{c}2760.2 \\
2760.2 \\
2762.4 \\
2756.0 \\
\ldots . . . . .\end{array}$ & $\begin{array}{l}6 \\
7 \\
3 \\
2\end{array}$ & $\begin{array}{r}-4.4 \\
-4.8 \\
=\quad 7.3 \\
-\quad .9 \\
0 . .6 . .\end{array}$ & $\begin{array}{r}2618.2 \\
2618.1 \\
2626.8 \\
\ldots \ldots . . .\end{array}$ & $\begin{array}{l}7 \\
3 \\
2\end{array}$ & $\begin{array}{r}+.3 \\
+\quad .0 \\
-9.0 \\
\ldots . . . .\end{array}$ \\
\hline $\begin{array}{l}6843 \\
6871 \\
6916 \\
6929 \\
6937\end{array}$ & $\begin{array}{l}\mathrm{Fe} \\
\mathrm{A} \\
\mathrm{Fe} \\
\mathrm{IVe} \\
\mathrm{A}\end{array}$ & . & & & $\begin{array}{l}2750.9 \\
2757.6 \\
2754.5\end{array}$ & $\begin{array}{l}2 \\
7 \\
2\end{array}$ & $\begin{array}{l}+3.1 \\
\ldots .1 .0 \\
-1.1\end{array}$ & $\begin{array}{r}2609.4 \\
2633.3 \\
2618.4\end{array}$ & $\begin{array}{l}2 \\
2 \\
3\end{array}$ & $\begin{array}{l}+7.6 \\
\cdots \ldots . . . \\
-16.8 \\
-2.0\end{array}$ \\
\hline $\begin{array}{l}6945 \\
6965 \\
6978 \\
7016 \\
7023\end{array}$ & $\begin{array}{l}\mathrm{Fe} \\
\mathrm{A} \\
\mathrm{Fe} \\
\mathrm{Fe} \\
\mathrm{Fe}\end{array}$ & $\begin{array}{c}2899.7 \\
2903.9 \\
2909.1\end{array}$ & $\begin{array}{l}2 \\
2 \\
2\end{array}$ & $\begin{array}{l}+5.4 \\
+1.0 \\
-4.8\end{array}$ & $\begin{array}{l}2749.3 \\
2748.7 \\
2750.8 \\
2765.4\end{array}$ & $\begin{array}{l}5 \\
2 \\
3 \\
1\end{array}$ & $\begin{array}{r}+4.1 \\
+4.6 \\
+2.4 \\
-12.5 \\
\ldots \ldots . . .\end{array}$ & $\begin{array}{c}2621.3 \\
\cdots \ldots 14.5 \\
\cdots \cdots\end{array}$ & 2 & $\begin{array}{l}-5.2 \\
+1.5 \\
\ldots \ldots . .\end{array}$ \\
\hline $\begin{array}{l}7030 \\
7032 \\
7038 \\
7059 \\
7067\end{array}$ & $\begin{array}{l}\text { A } \\
\text { Ne } \\
\text { Fe } \\
\text { Ne } \\
\text { A }\end{array}$ & $\cdots$ & & & \begin{tabular}{r}
2749.0 \\
2757.1 \\
\hdashline 2737.0 \\
2748.7
\end{tabular} & \begin{tabular}{l}
2 \\
8 \\
\hdashline 1 \\
2
\end{tabular} & \begin{tabular}{r}
+3.7 \\
-4.4 \\
$\cdots$ \\
\hdashline 4.5 \\
+3.7
\end{tabular} & $\begin{array}{r}2617.4 \\
2610.1 \\
\hdashline \ldots . .\end{array}$ & 2 & $\begin{array}{r}1.9 \\
+5.4 \\
\end{array}$ \\
\hline $\begin{array}{l}7068 \\
7090 \\
7130 \\
7147 \\
7164\end{array}$ & $\begin{array}{l}\mathrm{Fe} \\
\mathrm{Fe} \\
\mathrm{Fe} \\
\mathrm{A} \\
\mathrm{Fe}\end{array}$ & $\begin{array}{l}2902.4 \\
2905.3 \\
2898.7 \\
2895.0\end{array}$ & $\begin{array}{r}2 \\
2 \\
2 \\
\cdots \\
2\end{array}$ & $\begin{array}{l}+1.6 \\
+1.5 \\
+4.8 \\
+8.3\end{array}$ & \begin{tabular}{l}
2767.1 \\
\hdashline 2757.6 \\
2749.9 \\
2761.2
\end{tabular} & $\begin{array}{l}1 \\
33 \\
2 \\
3\end{array}$ & $\begin{array}{r}-14.7 \\
\cdots 5.6 \\
+2.0 \\
-9.4\end{array}$ & $\begin{array}{r}2624.1 \\
2609.0 \\
\hdashline 2613.6\end{array}$ & $\begin{array}{c}2 \\
2 \\
2\end{array}$ & $\begin{array}{l}-8.8 \\
+\ldots .8 \\
+5.1 .0\end{array}$ \\
\hline $\begin{array}{l}7173 \\
7187 \\
7207 \\
7223 \\
7245\end{array}$ & $\begin{array}{l}\mathrm{Fe} \\
\mathrm{Fe} \\
\mathrm{Ne}\end{array}$ & 2905.7 & 2 & -3.0 & $\begin{array}{r}2756.7 \\
2749.3 \\
2752.9 \\
\hdashline 2752.6\end{array}$ & $\begin{array}{l}4 \\
4 \\
3 \\
0\end{array}$ & $\begin{array}{r}-5.0 \\
+2.3 \\
-1.5 \\
\cdots \\
-1.5\end{array}$ & $\begin{array}{c}2626.4 \\
2608.9 \\
2616.6\end{array}$ & 2 & $\begin{array}{r}-11.9 \\
+5.2 \\
-2.6\end{array}$ \\
\hline $\begin{array}{l}7272 \\
7293 \\
7372 \\
7383 \\
7389\end{array}$ & $\begin{array}{l}\mathrm{A} \\
\mathrm{Fe} \\
\mathrm{A} \\
\mathrm{A} \\
\mathrm{Fe}\end{array}$ & $\begin{array}{l}2914.5 \\
2897.7\end{array}$ & 2 & +3.8 & $\begin{array}{r}2748.8 \\
\ldots 2751.2 \\
2746.6 \\
\ldots \ldots \ldots . . .\end{array}$ & $\begin{array}{l}2 \\
2 \\
2\end{array}$ & \begin{tabular}{l}
+2.2 \\
\hdashline+.9 \\
+3.6
\end{tabular} & $\begin{array}{r}2622.4 \\
\hdashline 2611.8\end{array}$ & 2 & $\begin{array}{l}-8.7 \\
+1.3\end{array}$ \\
\hline $\begin{array}{l}7411 \\
7438 \\
7445 \\
7495 \\
7503\end{array}$ & $\begin{array}{l}\mathrm{Fe} \\
\mathrm{Ne} \\
\mathrm{Fe} \\
\mathrm{Fe} \\
\mathrm{A}\end{array}$ & \begin{tabular}{r}
2900.6 \\
\hdashline 2903.6 \\
2905.8
\end{tabular} & $\begin{array}{l}4 \\
4 \\
4\end{array}$ & \begin{tabular}{l}
+.7 \\
\hdashline 2.6 \\
-6.1
\end{tabular} & $\begin{array}{l}2751.9 \\
2742.4 \\
2756.2 \\
2764.5 \\
2748.3\end{array}$ & $\begin{array}{l}5 \\
3 \\
3 \\
5 \\
2\end{array}$ & $\begin{array}{r}-2.0 \\
+7.4 \\
+6.5 \\
-15.1 \\
+1.1\end{array}$ & $\begin{array}{r}2620.2 \\
2609.4 \\
2612.7\end{array}$ & $\begin{array}{l}4 \\
3 \\
4 \\
4\end{array}$ & $\begin{array}{l}-7.3 \\
+3.2 \\
-\quad .3\end{array}$ \\
\hline $\begin{array}{l}7511 \\
7514 \\
7531 \\
7568 \\
7586\end{array}$ & $\begin{array}{l}\mathrm{A} \\
\mathrm{Fe} \\
\mathrm{Fe} \\
\mathrm{Fe}\end{array}$ & $\begin{array}{l}2897.2 \\
2903.0\end{array}$ & 4 & -3.1 & $\begin{array}{l}2 \\
2 \\
2\end{array}$ & $\begin{array}{l}4 \\
2 \\
2\end{array}$ & $\begin{array}{r}-.4 \\
+\quad .4 \\
+8.5 \\
\ldots \ldots . .6 .\end{array}$ & $\begin{array}{l}2616.6 \\
2606.8 \\
2616.6\end{array}$ & $\begin{array}{l}4 \\
2 \\
2\end{array}$ & $\begin{array}{r}4.4 \\
+5.1 \\
-4.7\end{array}$ \\
\hline $\begin{array}{l}7620 \\
7635 \\
7664 \\
7710 \\
7724\end{array}$ & $\begin{array}{l}\mathrm{Fe} \\
\mathrm{A} \\
\mathrm{Fe} \\
\mathrm{Fe} \\
\mathrm{A}\end{array}$ & 2895.8 & $\ddot{4}$ & +3.8 & \begin{tabular}{c}
2748.1 \\
2746.1 \\
2748.1 \\
\hdashline 2744.9
\end{tabular} & $\begin{array}{l}4 \\
2 \\
3 \\
2\end{array}$ & \begin{tabular}{l}
+.5 \\
+2.4 \\
$+\quad .3$ \\
\hdashline. .1 .1
\end{tabular} & \begin{tabular}{c}
2594.7 \\
\hdashline 2611.2 \\
2611.2
\end{tabular} & $\begin{array}{l}2 \\
4 \\
2\end{array}$ & $\begin{array}{c}+6.9 \\
\ldots \ldots . .1 \\
+\quad .1 \\
\ldots \ldots . .\end{array}$ \\
\hline $\begin{array}{l}7748 \\
7780 \\
7832 \\
7937 \\
7945\end{array}$ & $\begin{array}{l}F \\
F \\
F \\
F\end{array}$ & $\begin{array}{l}2890.2 \\
2897.4 \\
2902.3 \\
2887.8 \\
2904.9\end{array}$ & $\begin{array}{l}4 \\
4 \\
4 \\
4 \\
2\end{array}$ & $\begin{array}{r}+8.9 \\
+1.5 \\
+3.8 \\
+10.1 \\
-7.0\end{array}$ & & $\begin{array}{l}4 \\
3 \\
2 \\
3 \\
4\end{array}$ & $\begin{array}{l}+6.2 \\
+\quad .4 \\
\pm 3.2 \\
+\quad 1.4 \\
-\quad .3\end{array}$ & $\begin{array}{l}2603.1 \\
2602.9 \\
2611.2 \\
2615.4 \\
2612.7\end{array}$ & $\begin{array}{l}4 \\
4 \\
4 \\
2 \\
2\end{array}$ & $\begin{array}{l}+7.7 \\
+7.7 \\
-\quad .8 \\
-5.6 \\
-2.9\end{array}$ \\
\hline $\begin{array}{l}7948 \\
7998 \\
8006 \\
8014 \\
8046\end{array}$ & $\begin{array}{l}\mathrm{A} \\
\mathrm{Fe} \\
\mathrm{A} \\
\mathrm{A} \\
\mathrm{Fe}\end{array}$ & $\begin{array}{l}2886.7 \\
\ldots \ldots \ldots \\
2890.3\end{array}$ & $\dddot{2}$ & $\begin{array}{l}+10.4 \\
\cdots \\
+7.2\end{array}$ & $\begin{array}{l}2748.7 \\
2745.8 \\
2743.6 \\
2750.1\end{array}$ & $\begin{array}{l}2 \\
2 \\
2 \\
2 \\
2\end{array}$ & $\begin{array}{l}+1.4 \\
-2.2 \\
+\quad .6 \\
+2.8 \\
-3.8\end{array}$ & $\begin{array}{l}2606.6 \\
2605.6\end{array}$ & $\dddot{2}$ & $\begin{array}{l}+2.9 \\
+3.6\end{array}$ \\
\hline
\end{tabular}


TABLE 2-Continued

\begin{tabular}{|c|c|c|c|c|c|c|c|c|c|c|}
\hline$\lambda \mathbf{A}$ & Source & $\begin{array}{l}\text { Obser- } \\
\text { vations, } \\
0^{\circ} \mathrm{C}, \\
760 \mathrm{~mm}\end{array}$ & $\begin{array}{l}\text { Num- } \\
\text { ber of } \\
\text { obser- } \\
\text { vations }\end{array}$ & $\begin{array}{c}\text { Com- } \\
\text { puted } \\
\text { minus ob- } \\
\text { served }\end{array}$ & $\begin{array}{l}\text { Obser- } \\
\text { vations, } \\
15^{\circ} \mathrm{C}, \\
760 \mathrm{~mm}\end{array}$ & $\begin{array}{l}\text { Num- } \\
\text { ber of } \\
\text { obser- } \\
\text { vations }\end{array}$ & $\begin{array}{l}\text { Com- } \\
\text { puted } \\
\text { minns ob- } \\
\text { served }\end{array}$ & $\begin{array}{l}\text { Obser- } \\
\text { vations, } \\
30^{\circ} \mathrm{C} \text {. } \\
760 \mathrm{~mm}\end{array}$ & $\begin{array}{l}\text { Num- } \\
\text { ber of } \\
\text { obser- } \\
\text { vations }\end{array}$ & $\begin{array}{l}\text { Com- } \\
\text { puted } \\
\text { minus ob- } \\
\text { served }\end{array}$ \\
\hline \multirow{2}{*}{$\begin{array}{l}8085 \\
8103 \\
8115 \\
8220 \\
8264\end{array}$} & \multirow{2}{*}{$\begin{array}{l}\mathrm{Fe} \\
\mathrm{A} \\
\mathrm{A} \\
\mathrm{Fe} \\
\mathrm{A}\end{array}$} & 6 & 2 & & \multirow{2}{*}{$\begin{array}{l}2739.2 \\
2742.8 \\
2742.0 \\
2736.1 \\
2742.5\end{array}$} & \multirow{2}{*}{$\begin{array}{l}2 \\
1 \\
1 \\
2 \\
1\end{array}$} & \multirow{2}{*}{$\begin{array}{r}+6.9 \\
+\quad 3.2 \\
+3.9 \\
+\quad 9.3 \\
+\quad 2.7\end{array}$} & 2610.0 & 2 & -0.9 \\
\hline & & 2695.2 & 2 & +1.2 & & & & 2612.2 & 3 & -3 \\
\hline \multirow{2}{*}{$\begin{array}{l}8327 \\
8387 \\
8408 \\
8424 \\
8+68\end{array}$} & \multirow{2}{*}{$\begin{array}{l}\mathrm{Fe} \\
\mathrm{Fe} \\
\mathrm{A} \\
\mathrm{A} \\
\mathrm{Fe}\end{array}$} & & 2 & +1 & \multirow{2}{*}{$\begin{array}{l}2738.8 \\
2741.2 \\
2743.6 \\
2742.7\end{array}$} & \multirow{2}{*}{$\begin{array}{l}3 \\
3 \\
1 \\
1\end{array}$} & \multirow{2}{*}{$\begin{array}{r}+6.1 \\
+\quad 3.4 \\
+\quad .9 \\
+1.7\end{array}$} & & $\begin{array}{l}3 \\
3\end{array}$ & $\begin{array}{r}+1.3 \\
+8.4\end{array}$ \\
\hline & & 2900.1 & $\dddot{i}$ & -5.0 & & & & 2606.6 & 3 & +.7 \\
\hline \multirow{2}{*}{$\begin{array}{l}8514 \\
8521 \\
8611 \\
8561 \\
8674\end{array}$} & \multirow{2}{*}{$\begin{array}{l}\mathrm{Fe} \\
\mathrm{A} \\
\mathrm{Fe} \\
\mathrm{Fe} \\
\mathrm{Fe}\end{array}$} & & & & $\begin{array}{l}2745.9 \\
2746.3\end{array}$ & & $\begin{array}{l}-1.8 \\
-2.3\end{array}$ & 2 & $\begin{array}{l}3 \\
\ldots\end{array}$ & $\begin{array}{l}+2.8 \\
0\end{array}$ \\
\hline & & 2881.0 & 2 & 13. 2 & 2740.7 & 1 & +2.7 & & $\begin{array}{l}1 \\
4 \\
1\end{array}$ & $\begin{array}{r}+7.7 \\
+5.5 \\
-6.1\end{array}$ \\
\hline $\begin{array}{l}8688 \\
8824 \\
8999\end{array}$ & $\begin{array}{l}\mathrm{Fe} \\
\mathrm{Fe}_{0}\end{array}$ & 3 & 2 & +6 & & $\begin{array}{l}2 \\
1 \\
1\end{array}$ & +5 & & $\begin{array}{l}4 \\
4 \\
2\end{array}$ & \\
\hline $8 \%$ & & & & & & 1 & & & 2 & \\
\hline
\end{tabular}

3. THE CAUCHY DISPERSION FORMULA

The empirical Cauchy formula

$$
n-\mathrm{I}=a+\frac{b}{\lambda^{2}}+\frac{c}{\lambda^{4}}
$$

was used to represent these observations of refractivity as a function of the wave length. All the measurements on the refractivity of air at a particular temperature were grouped at intervals of $200 \mathrm{~A}$ with the aid of the dispersion formula given by Miss Howell ${ }^{43}$. This gave 34 observational equations from which were obtained the three normal equations required to solve for the three constants of the Cauchy formula by the method of least squares. This solution was made independently for the observations at each of the three temperatures and gave the following equations:

$$
\begin{aligned}
& 0^{\circ} \mathrm{C},(n-\mathrm{I}) 10^{7}=2875.66+\frac{\mathrm{I} 3.412}{\lambda^{2} \times 10^{-8}}+\frac{0.3777}{\lambda^{4} \times 10^{-10}} \\
& 15^{\circ} \mathrm{C},(n-\mathrm{I}) 10^{7}=2726.43+\frac{12.288}{\lambda^{2} \times 10^{-8}}+\frac{0.3555}{\lambda^{4} \times 10^{-10}} \\
& 30^{\circ} \mathrm{C},(n-\mathrm{I}) 10^{7}=2589.72+\frac{\mathrm{I} 2.259}{\lambda^{2} \times 10^{-8}}+\frac{0.2576}{\lambda^{4} \times 10^{-18}}
\end{aligned}
$$

These equations are represented graphically in Fig. 7 . 


The algebraic sum of differences of the grouped observations from the equation values is zero, but this is not quite true of the residuals of the individual observations as given in Table 2 . The reason for this is that equal weight was given to the 34 values which represented the observations in $200 \mathrm{~A}$ intervals whereas some of them represented slightly more concordant, or a larger number of observations than others.

A total of II 65 index measurements were made:

277 for 122 different wave lengths in air at $0^{\circ} \mathrm{C}$,

513 for 185 different wave lengths in air at $15^{\circ} \mathrm{C}$, and 375 for 154 different wave lengths in air at $30^{\circ} \mathrm{C}$.

In view of the large number of observations which are fairly well distributed throughout the spectrum and quite concordant it is considered that their collection to 34 points, as explained above, gives dispersion equations which are a sufficiently accurate representation of the observations. The deviations of the individual observations from the computed curves indicate a probable error of 3.8 in a single $(n-1) 10^{7}$ for air at $0^{\circ} \mathrm{C}$, 3.I for air at I $5^{\circ} \mathrm{C}$, and 2.9 for air at $30^{\circ} \mathrm{C}$.

\section{SOURCES OF ERROR}

Although the normal volume percentage of carbon dioxide in the atmosphere at the earth's surface is 0.03 , the amount present in even a well-ventilated laboratory with persons present may be twice as large. The index of refraction of carbon dioxide for visible light is about I.00045 so that the normal amount in the atmosphere contributes little more than one unit in the seventh decimal place of the index of refraction of air. The error introduced in the measurement of the index of refraction of air in a laboratory containing as much as twice the normal amount of carbon dioxide is, therefore, even less than one unit in the seventh decimal place since the increase in carbon dioxide is accompanied by a decrease in oxygen whose index is about 1.00027 .

A source of error which has not been mentioned in previous applications of the interferometer to measurement of indices of refraction was called to our attention by Dr. W. F. G. Swann and is due to different dimensions of the apparatus under different pressures. The etalon posts separating the plates of the Fabry and Perot interferometer are larger in a vacuum than they are when surrounded by air at atmospheric pressure. The bulk modulus of invar indicates that the length of these posts is about 2 parts in 3000000 less in air than in vacuum. If this compres- 


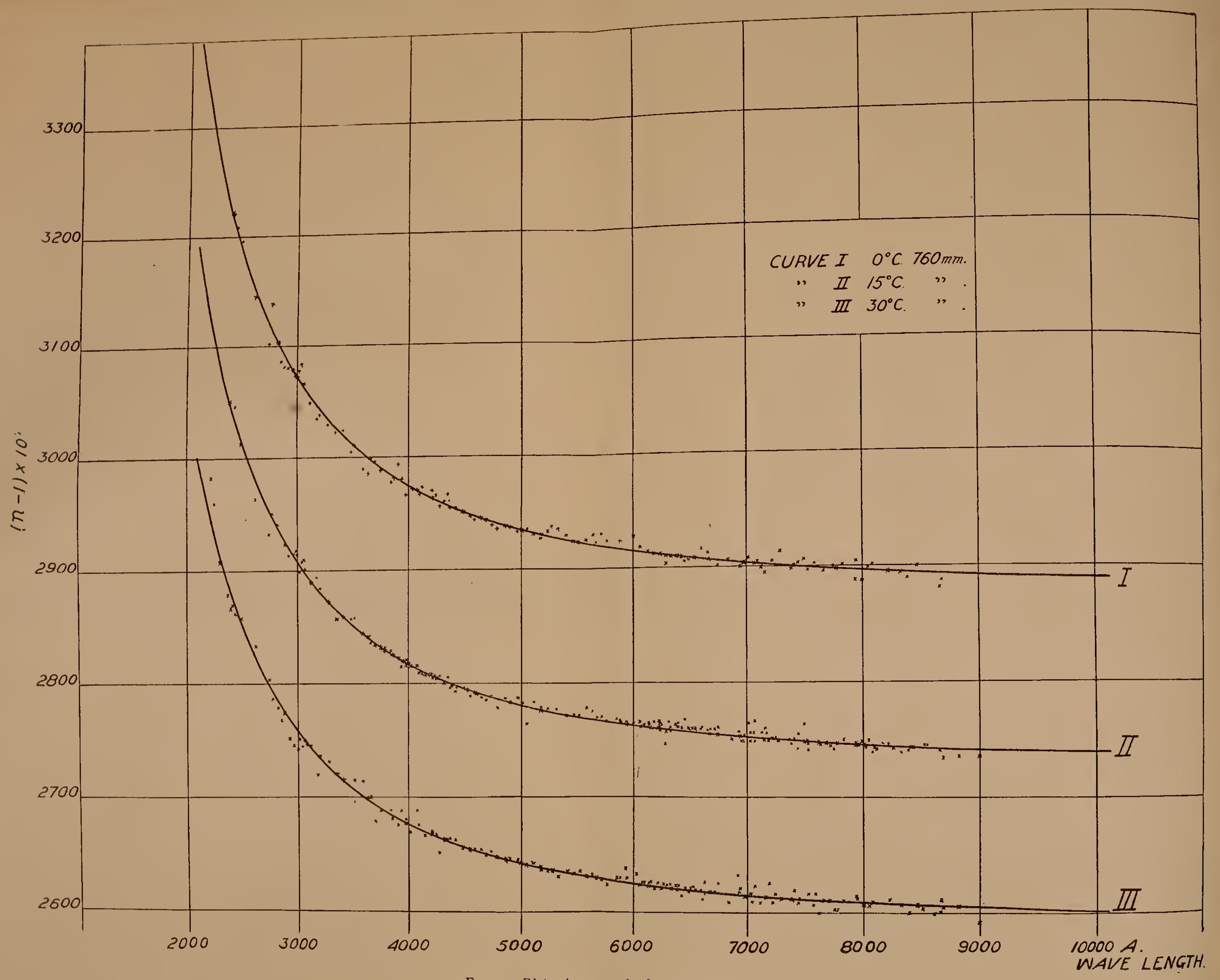



sion is not taken into account in the calculations, the value of the index of refraction will be about one unit too small in the seventh decimal place. However, this correction can not be applied definitely since the effect of similar compression on other parts of the apparatus holding the interferometer plates can not be computed accurately.

It was, at first, thought possible that an error might be introduced by differences of phase change at reflection from the interferometer plates in air and vacuum. If the film of adsorbed gas on the interferometer plates is different at different pressures, it might become evident as a change in the phase correction to wave lengths. Etalons of various sizes from 3 to $25 \mathrm{~mm}$ were used in these experiments and the differences in phase change at reflection suffered by different wave lengths were found by a method previously described."4 The same relative phase changes were found with low pressures as with atmospheric pressures of air on the plates and the absolute phase changes may be assumed to remain constant also. Furthermore, experiments on contact differences of potential show that films of adsorbed gas are quite stable and only show changes after several hours in very high vacuum.

It appears that the systematic errors which affect these measurements of the refractive index of air are extremely small and more or less compensating. The index is increased slightly by the extra carbon dioxide in laboratory air but this increase is probably of the same order of magnitude as the decrease due to the compression of the etalon. It seems safe to assume, therefore, that these systematic errors in our measurements of the index of refraction of air are entirely negligible.

\section{APPLICATIONS}

\section{CORRECTION OF WAVE LENGTH MEASUREMENTS MADE IN AIR AT OTHER THAN NORMAL TEMPERATURES AND PRESSURES}

The international wave length standards are represented by specified radiations whose wave lengths were measured in dry air at $15^{\circ} \mathrm{C}$ exerting a barometric pressure equivalent to $760 \mathrm{~mm}$ of mercury. ${ }^{45}$ These standards serve as a basis for the precise measurement of all other wave lengths. Variations in the density of the air appreciably affect the absolute values of the wave lengths and when wave length measurements are made in air whose temperature is not $15^{\circ} \mathrm{C}$, or whose pressure is not equal to $760 \mathrm{~mm}$,

" This Bulletin, 12. D. 193; 1915-1916.

* Astroph. Jl., 32, p. 215. 1910: 83, p. 85, 1911; 39, p. 93, 1914. 
corrections must be applied to the measured values to reduce them to their values in air under normal conditions. If the index of refraction of air were a constant throughout the spectrum, all the wave lengths would vary in the same ratio, but the dispersion of the air makes this variation a function of the absolute index and of the density of the air at the time the wave length comparisons were made. For example, let a wave length $\lambda$ be measured in terms of a standard wave length $\lambda^{\prime}$ and consider the result if the measurement is made in air whose density is greater than that defined by the normal conditions. The indices of refraction $n$ and $n^{\prime}$ for these two wave lengths increase proportionately with the density of the air and the wave lengths decrease. But if $\lambda$ is smaller than $\lambda^{\prime}$, the absolute index of refraction $n$ is larger than $n^{\prime}$ and the increase in index due to the increased density of air will be a larger amount for $n$ than for $n^{\prime}$. Consequently $\lambda$ is proportionately shorter than $\lambda^{\prime}$ in denser air and requires a positive correction to make it comparable with $\lambda^{\prime}$ in air at $15^{\circ} \mathrm{C}$ and $760 \mathrm{~mm}$.

The effect of the temperature and pressure of the air must be taken into account in all accurate comparisons of wave lengths made either by the coincidence method with diffraction grating $\mathrm{s}^{48}$ or with interferometers. ${ }^{47}$ The necessary corrections are generally small and may be negligible under certain conditions. In order actually to calculate these corrections let us imagine the wavelength comparisons to be made by means of an interferometer in air whose density, $d$, is defined by the temperature $t$ and the barometric pressure $B$. Let $\lambda$ represent the wave length of a radiation under these conditions, $n$ the index of refraction of this air for this wave length, and $\lambda^{\prime}$ and $n^{\prime}$ analogous quantities for the standard wave length with which $\lambda$ is to be compared. The same letters with the subscript $o$ may be used to represent the same quantities under standard observing conditions; that is, air at I $5^{\circ} \mathrm{C}$ and $760 \mathrm{~mm}$. It is desired to obtain $\lambda_{0}$. The orders of interference measured under the actual conditions give $p \lambda=p^{\prime} \lambda^{\prime}$ $(=2 e)$. The calculation for $\lambda$, however, is made from $\frac{\dot{p}^{\prime} \lambda_{0}^{\prime}}{p}$ in which the standard wave length is used as if the air had no dispersion, and then a correction is applied.

\footnotetext{
${ }^{16}$ Kayser, Handbuch der Spectroscopie, 1, p. 719; 1900.

47 Buisson arld Fabry, Jour. de Phys., 7, p. 169; 1908.

$110990^{\circ}-19-16$
} 
This correction, the difference between the exact value and that calculated, is equal to

$$
\delta=\lambda_{0}-\frac{p^{\prime} \lambda_{0}^{\prime}}{p}=\lambda_{0}\left(\mathrm{I}-\frac{p^{\prime} \lambda_{0}^{\prime}}{p \lambda_{0}}\right)=\lambda_{0}\left(\mathrm{I}-\frac{\lambda \lambda_{0}^{\prime}}{\lambda^{\prime} \lambda_{0}}\right)
$$

But

$$
\frac{\lambda}{\lambda_{0}}=\frac{n_{\mathrm{o}}}{n} \text { and } \frac{\lambda^{\prime}}{\lambda_{\mathrm{o}}^{\prime}}=\frac{n_{\mathrm{o}}^{\prime}}{n^{\prime}}
$$

Then

$$
\delta=\lambda_{\mathrm{o}}\left(\mathrm{I}-\frac{n_{\mathrm{o}} n^{\prime}}{n_{\mathrm{o}}^{\prime} n}\right)=\lambda_{\mathrm{o}} \frac{n_{\mathrm{o}}{ }^{\prime} n-n_{\mathrm{o}} n^{\prime}}{n_{\mathrm{o}}^{\prime} n}=\lambda_{\mathrm{o}}\left(n_{\mathrm{o}}{ }^{\prime} n-n_{\mathrm{o}} n^{\prime}\right)
$$

since $n_{\mathrm{o}}{ }^{\prime} n$ in the denominator may be called unity. Assuming the refractivity to be proportional to the density

$$
\frac{n-\mathrm{I}}{d}=\frac{n_{\mathrm{o}}-\mathrm{I}}{d_{\mathrm{o}}} \text { and } \frac{n^{\prime}-\mathrm{I}}{d}=\frac{n_{\mathrm{o}}^{\prime}-\mathrm{I}}{d_{\mathrm{o}}}
$$

we have

$$
n=\frac{\left(n_{\mathrm{o}}-\mathrm{I}\right) d}{d_{\mathrm{o}}}+\mathrm{I} \text { and } n^{\prime}=\frac{\left(n_{\mathrm{o}}^{\prime}-\mathrm{I}\right) d}{d_{\mathrm{o}}}+\mathrm{I}
$$

and the correction reduces to

$$
\delta=\lambda_{\mathrm{o}}\left(n_{\mathrm{o}}-n_{\mathrm{o}}^{\prime}\right) \frac{d-d_{\mathrm{o}}}{d_{\mathrm{o}}}
$$

The factor $\frac{d-d_{0}}{d_{0}}$ is easily calculated as a function of temperature and pressure, and is constant for all the waves compared under these conditions.

The quantity $\lambda_{0}\left(n_{0}-n_{0}{ }^{\prime}\right)$ may be calculated as a function of the wave length and represented by a curve from which the correction to the wave length can be obtained by multiplying its ordinate by the appropriate density factor $\frac{d-d_{\mathrm{o}}}{d_{\mathrm{o}}}$.

In order to avoid all these troublesome computations hereafter, Tables 3 and 4 have been prepared to give these corrections for the entire range of wave lengths and densities of air in which accurate spectroscopic measurements are ordinarily made. Table 3 gives the density factor $\frac{d-d_{\mathrm{o}}}{d_{\mathrm{o}}}$ in terms of the temperature $t$ of the 
air in centigrade degrees and the barometric pressure $B$ of the air in millimeters of mercury.

Table 4 gives the corrections, $\delta=\lambda_{\mathrm{o}}\left(n_{\mathrm{o}}-n_{\mathrm{o}}{ }^{\prime}\right) \frac{a-d_{\mathrm{o}}}{d_{\mathrm{o}}}$, in tenthousandths of an Angstrom. These tables are constructed for the correction of wave length measurements in terms of the fundamental spectroscopic standard; that is, the wave length 6438.4696 $\mathrm{A}$ of cadmium red radiation in dry air at $15^{\circ} \mathrm{C}$ and $760 \mathrm{~mm}$. The density factor (Table 3 ) is therefore zero for $t=15^{\circ} \mathrm{C}$ and $B=760$ $\mathrm{mm}$., and the correction (Table 4 ) is always zero for $\lambda=6438 \mathrm{~A}$.

To illustrate the use of these tables, find the correction required by $\lambda$ when it is measured as $3000.0000 \mathrm{~A}$ in air at $25^{\circ} \mathrm{C}$ and 720 mm. Table 3 gives $\frac{d-d_{0}}{d_{0}}=-0.085$ and this in Table 4 gives a correction of $-0.0038 \mathrm{~A}$ to $\lambda$. Again, if $\lambda$, under the same atmospheric conditions, is measured as $8000.0000 \mathrm{~A}$ in terms of a standard $\lambda^{\prime}$ of wave length $4000.0000 \mathrm{~A}$, say, the measurement will require a correction of $(0.0020+0.0008=)+0.0028 \mathrm{~A}$. By easy interpolation in these tables the corrections can be found for all wave lengths between $2000 \mathrm{~A}$ and $10000 \mathrm{~A}$ when the wave length comparisons are made in air whose density is determined by a temperature range from 9 to $35^{\circ} \mathrm{C}$ and a pressure range from 600 to $780 \mathrm{~mm}$. of mercury.

\section{CORRECTIONS FOR WATER VAPOR IN THE AIR}

The refractive index of water vapor has not been fully investigated and the corrections necessary to change wave lengths measured in wet air to their values in dry air are therefore not very accurately known. Lorenz measured the index of refraction of water vapor (specific gravity $=0.000806 \mathrm{I}$ ) for sodium light as 1.0002500. From this result he recommends a correction of $+0.00004 \mathrm{r} \frac{m}{760}$ to indices of refraction measured in air containing water vapor of $m$ millimeters pressure.

No measurements on the dispersion of water vapor are known to exist, but if the dispersion is assumed to be comparable with that of air, the corrections to relative wave lengths will not be affected, since they depend on the difference of indices $n_{0}-n_{\circ}^{\prime}$.

Two of our experiments on the dispersion of air for waves between $5800 \mathrm{~A}$ and $7500 \mathrm{~A}$ were made with air having a water vapor pressure of $13 \mathrm{~mm}$. The index of refraction was observed to be diminished by approximately the amount given by the Lorenz 


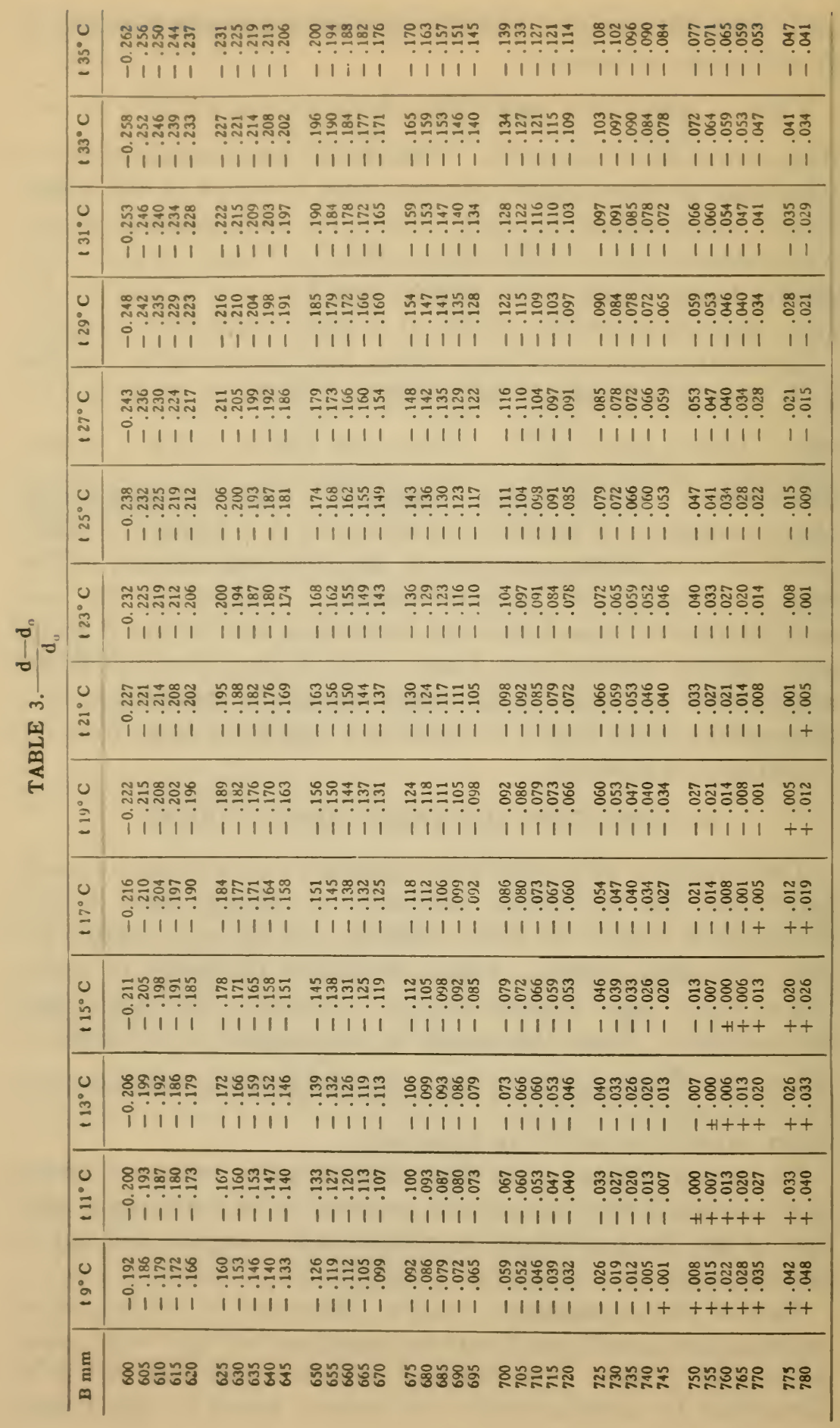




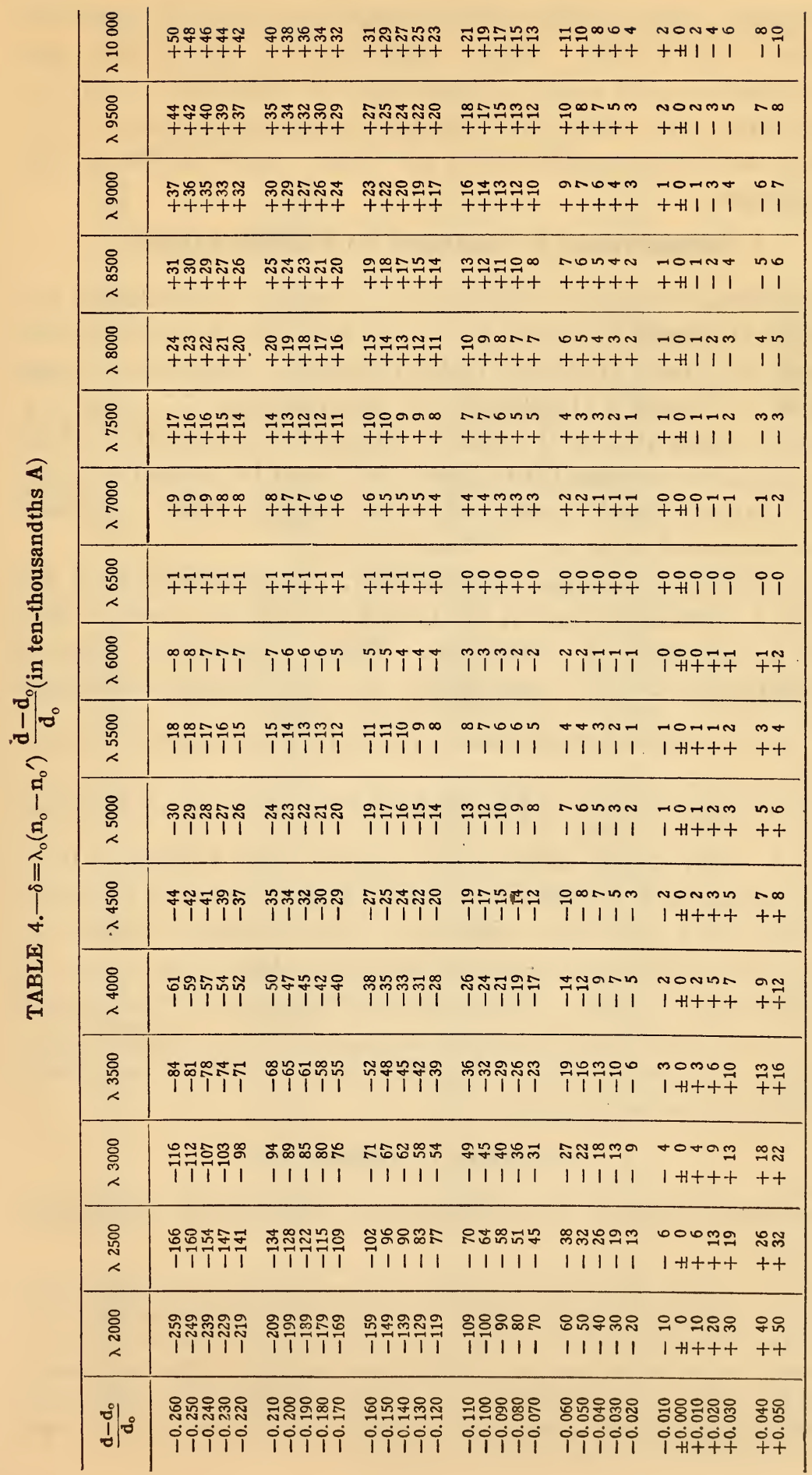


expression. Furthermore, this decrease was about the same for different wave lengths. These results on wet air are not complete enough to add much to the subject of dispersion of light by water vapor, but they show that the corrections to index of refraction as recommended above for water vapor in the air are quite proper.

\section{CORRECTIONS TO CONVERT TO VACUUM VALUES}

Corrections required to convert wave lengths or oscillation frequencies measured in air at $20^{\circ} \mathrm{C}$ and $760 \mathrm{~mm}$ to their value in vacuum are found in Watts' Index of Spectra, appendix E, page 5I, and in Kayser's Handbuch der Spectroscopie, II, page 5 I 3. These are applicable to Rowland's standard wave lengths and all wave lengths determined from them, but must be revised to apply to the international system of wave lengths which represent values measured in air at $15^{\circ} \mathrm{C}$ and $760 \mathrm{~mm}$.

The dispersion equation representing. our observations on the indices of refraction of air at $15^{\circ} \mathrm{C}$ and $760 \mathrm{~mm}$ was used to construct a new table of corrections. Table 5 gives the values of wave length in air, $(\lambda)$, refractivity, $(n-1) I^{7}$, vacuum correction to $\lambda,(n \lambda-\lambda)$, oscillation frequency in air, $\left(\frac{1}{\lambda}\right)$, and vacuum correction to frequency, $\left(\frac{\mathrm{I}}{n \lambda}-\frac{\mathrm{I}}{\lambda}\right)$, from $2000 \mathrm{~A}$ to $\mathrm{I} 0000 \mathrm{~A}$ at intervals of $50 \mathrm{~A}$. This table shows, for example, that a light wave of length $5000.000 \mathrm{~A}$ in dry air at $15^{\circ} \mathrm{C}$ and $760 \mathrm{~mm}$ is increased in length by $1.39 \mathrm{I} \mathrm{A}$ in a vacuum. The frequency (number of waves per centimeter) in air is 20000.00 , but in a vacuum it is diminished by 5.56 . The vacuum frequencies corresponding to any wave lengths in the international scale can be readily determined by the use of Table 5 together with a table of reciprocals with seven place arguments.

\section{ASTRONOMICAL REFRACTION}

Newcomb states in his Compendium of Spherical Astronomy, page 223:

There is, perhaps, no branch of practical astronomy on which so much has been written as on this (astronomical refraction) and which is still in so unsatisfactory a state. The difficulties connected with it are both theoretical and practical. The theoretical difficulties arise from the uncertainty and variability of the law of diminution of the density of the atmosphere with height, and also from the mathematical difficulty of integrating the equations of the refraction for altitudes near the horizon, after the best law of diminution has been adopted. 
TABLE 5.-Table of corrections to be Applied to Wave Lengths in Air at $15^{\circ} \mathrm{C}$ and $760 \mathrm{~mm}$ to Reduce Wave Lengths and Frequencies to Vacuum Values

\begin{tabular}{|c|c|c|c|c|}
\hline$\lambda$ & $(n-1) 10^{7}$ & $\underset{\text { add }}{(n \lambda-\lambda)}$ & $\frac{1}{\lambda}$ & $\underset{\text { subtract }}{\left(\frac{1}{n \lambda}-\frac{1}{\lambda}\right)}$ \\
\hline $\begin{array}{l}2000 \\
2050 \\
2100 \\
2150 \\
2200\end{array}$ & $\begin{array}{l}3255.82 \\
3220.12 \\
3187.86 \\
3158.63 \\
3132.07\end{array}$ & $\begin{array}{r}0.6512 \\
.6601 \\
.6695 \\
.6791 \\
.6891\end{array}$ & $\begin{array}{l}50000 \\
48780 \\
47619 \\
46511 \\
45 \quad 454\end{array}$ & $\begin{array}{l}16.274 \\
15.703 \\
15.175 \\
14.687 \\
14.232\end{array}$ \\
\hline $\begin{array}{l}2250 \\
2300 \\
2350 \\
2400 \\
2450\end{array}$ & $\begin{array}{l}3107.87 \\
3085.75 \\
3065.50 \\
3046.91 \\
3029.81\end{array}$ & $\begin{array}{l}.6993 \\
.7097 \\
.7204 \\
.7313 \\
.7423\end{array}$ & $\begin{array}{ll}44 & 444 \\
43 & 478 \\
42 & 553 \\
41 & 666 \\
40 & 816\end{array}$ & $\begin{array}{l}13.808 \\
13.412 \\
13.041 \\
12.692 \\
12.363\end{array}$ \\
\hline $\begin{array}{l}2500 \\
2550 \\
2600 \\
2650 \\
2700\end{array}$ & $\begin{array}{l}3014.05 \\
2999.48 \\
2986.00 \\
2973.50 \\
2961.88\end{array}$ & $\begin{array}{l}.7535 \\
.7649 \\
.7764 \\
.7880 \\
.7997\end{array}$ & $\begin{array}{ll}40 & 000 \\
39 & 215 \\
38 & 451 \\
37 & 735 \\
37 & 037\end{array}$ & $\begin{array}{l}12.053 \\
11.759 \\
11.481 \\
11.217 \\
10.967\end{array}$ \\
\hline $\begin{array}{l}2750 \\
2800 \\
2850 \\
2900 \\
2950\end{array}$ & $\begin{array}{l}2951.08 \\
2941.00 \\
2931.60 \\
2922.80 \\
2914.57\end{array}$ & $\begin{array}{l}.8115 \\
.8235 \\
.8355 \\
.8476 \\
.8598\end{array}$ & $\begin{array}{ll}36 & 363 \\
35 & 714 \\
35 & 087 \\
34 & 482 \\
33 & 898\end{array}$ & $\begin{array}{r}10.728 \\
10.500 \\
10.283 \\
10.076 \\
9.877\end{array}$ \\
\hline $\begin{array}{l}3000 \\
3050 \\
3100 \\
3150 \\
3200\end{array}$ & $\begin{array}{l}2906.85 \\
2899.60 \\
2892.79 \\
2886.38 \\
2880.33\end{array}$ & $\begin{array}{l}.8721 \\
.8844 \\
.8968 \\
.9092 \\
.9217\end{array}$ & $\begin{array}{ll}33 & 333 \\
32 & 786 \\
32 & 258 \\
31 & 746 \\
31 & 250\end{array}$ & $\begin{array}{l}9.687 \\
9.504 \\
9.329 \\
9.160 \\
8.998\end{array}$ \\
\hline $\begin{array}{l}3250 \\
3300 \\
3350 \\
3400 \\
3450\end{array}$ & $\begin{array}{l}2874.63 \\
2869.24 \\
2864.15 \\
2859.33 \\
2854.76\end{array}$ & $\begin{array}{l}.9343 \\
.9469 \\
.9595 \\
.9722 \\
.9849\end{array}$ & $\begin{array}{ll}30 & 769 \\
30 & 303 \\
29 & 850 \\
29 & 411 \\
28 & 985\end{array}$ & $\begin{array}{l}8.842 \\
8.692 \\
8.547 \\
8.407 \\
8.272\end{array}$ \\
\hline $\begin{array}{l}3500 \\
3550 \\
3600 \\
3650 \\
3700\end{array}$ & $\begin{array}{l}2850.43 \\
2846.32 \\
2842.41 \\
2838.69 \\
3835.16\end{array}$ & $\begin{array}{r}.9977 \\
1.0104 \\
1.0233 \\
1.0361 \\
1.0490\end{array}$ & $\begin{array}{ll}28 & 571 \\
28 & 169 \\
27 & 777 \\
27 & 397 \\
27 & 027\end{array}$ & $\begin{array}{l}8.142 \\
8.016 \\
7.893 \\
7.774 \\
7.660\end{array}$ \\
\hline $\begin{array}{l}3750 \\
3800 \\
3850 \\
3900 \\
3950\end{array}$ & $\begin{array}{l}2831.79 \\
2828.58 \\
2825.51 \\
2822.59 \\
2819.79\end{array}$ & $\begin{array}{l}1.0619 \\
1.0749 \\
1.0878 \\
1.1008 \\
1.1138\end{array}$ & $\begin{array}{ll}26 & 666 \\
26 & 315 \\
25 & 974 \\
25 & 641 \\
25 & 316\end{array}$ & $\begin{array}{l}7.550 \\
7.442 \\
7.337 \\
7.235 \\
7.137\end{array}$ \\
\hline $\begin{array}{l}4000 \\
4050 \\
4100 \\
4150 \\
4200\end{array}$ & $\begin{array}{l}2817.12 \\
2814.56 \\
2812.11 \\
2809.76 \\
2807.51\end{array}$ & $\begin{array}{l}1.1268 \\
1.1399 \\
1.1530 \\
1.1661 \\
1.1792\end{array}$ & $\begin{array}{ll}25 & 000 \\
24 & 691 \\
24 & 390 \\
24 & 096 \\
23 & 809\end{array}$ & $\begin{array}{l}7.041 \\
6.948 \\
6.857 \\
6.769 \\
6.683\end{array}$ \\
\hline $\begin{array}{l}4250 \\
4300 \\
4350 \\
4400 \\
4450\end{array}$ & $\begin{array}{l}2805.36 \\
2803.29 \\
2801.30 \\
2799.39 \\
2797.55\end{array}$ & $\begin{array}{l}1.1923 \\
1.2054 \\
1.2186 \\
1.2317 \\
1.2449\end{array}$ & $\begin{array}{ll}23 & 529 \\
23 & 255 \\
22 & 988 \\
22 & 727 \\
22 & 471\end{array}$ & $\begin{array}{l}6.599 \\
6.517 \\
6.437 \\
6.360 \\
6.285\end{array}$ \\
\hline $\begin{array}{l}4500 \\
4550 \\
4600 \\
4650 \\
4700\end{array}$ & $\begin{array}{l}2795.78 \\
2794.08 \\
2792.44 \\
2790.86 \\
2789.34\end{array}$ & $\begin{array}{l}1.2581 \\
1.2713 \\
1.2845 \\
1.2978 \\
1.3110\end{array}$ & $\begin{array}{ll}22 & 222 \\
21 & 978 \\
21 & 739 \\
21 & 505 \\
\cdot 21 & 276\end{array}$ & $\begin{array}{l}6.211 \\
6.139 \\
6.069 \\
6.000 \\
5.933\end{array}$ \\
\hline $\begin{array}{l}4750 \\
4800 \\
4850 \\
4900 \\
4950\end{array}$ & $\begin{array}{l}2787.88 \\
2786.46 \\
2785.09 \\
2783.78 \\
2782.50\end{array}$ & $\begin{array}{l}1.3242 \\
1.3375 \\
1.3508 \\
1.3640 \\
1.3773\end{array}$ & $\begin{array}{ll}21 & 052 \\
20 & 833 \\
20 & 618 \\
20 & 406 \\
20 & 202\end{array}$ & $\begin{array}{l}5.868 \\
5.804 \\
5.741 \\
5.680 \\
5.620\end{array}$ \\
\hline $\begin{array}{l}5000 \\
5050 \\
5100 \\
5150 \\
5200\end{array}$ & $\begin{array}{l}2781.27 \\
2780.08 \\
2778.93 \\
2777.81 \\
2776.74\end{array}$ & $\begin{array}{l}1.3906 \\
1.4039 \\
1.4173 \\
1.4306 \\
1.4439\end{array}$ & $\begin{array}{ll}20 & 000 \\
19 & 801 \\
19 & 607 \\
19 & 417 \\
19 & 230\end{array}$ & $\begin{array}{l}5.561 \\
5.503 \\
5.447 \\
5.392 \\
5.336\end{array}$ \\
\hline
\end{tabular}


TABLE 5-Continued

\begin{tabular}{|c|c|c|c|c|}
\hline$\lambda$ & $(n-1) 10^{2}$ & $\underset{\text { add }}{(n \lambda-\lambda)}$ & $\frac{1}{\lambda}$ & $\underset{\text { subtract }}{\left(\frac{1}{n \lambda}-\frac{1}{\lambda}\right)}$ \\
\hline $\begin{array}{l}5250 \\
5300 \\
5350 \\
5400 \\
5450\end{array}$ & $\begin{array}{l}2775.69 \\
2774.68 \\
2773.70 \\
2772.75 \\
2771.83\end{array}$ & $\begin{array}{l}1.4572 \\
1.4706 \\
1.4839 \\
1.4973 \\
1.5106\end{array}$ & $\begin{array}{ll}19 & 047 \\
18 & 867 \\
18 & 691 \\
18 & 518 \\
18 & 348\end{array}$ & $\begin{array}{l}5.285 \\
5.234 \\
5.183 \\
5.133 \\
5.084\end{array}$ \\
\hline $\begin{array}{l}5500 \\
5550 \\
5600 \\
5650 \\
5700\end{array}$ & $\begin{array}{l}2770.94 \\
2770.07 \\
2769.23 \\
2768.41 \\
2767.62\end{array}$ & $\begin{array}{l}1.5240 \\
1.5374 \\
1.5508 \\
1.5642 \\
1.5775\end{array}$ & $\begin{array}{ll}18 & 181 \\
18 & 018 \\
17 & 857 \\
17 & 699 \\
17 & 543\end{array}$ & $\begin{array}{l}5.037 \\
4.990 \\
4.944 \\
4.899 \\
4.854\end{array}$ \\
\hline $\begin{array}{l}5750 \\
5800 \\
5850 \\
5900 \\
5950\end{array}$ & $\begin{array}{l}2766.85 \\
2766.10 \\
2765.37 \\
2764.66 \\
2763.98\end{array}$ & $\begin{array}{l}1.5909 \\
1.6043 \\
1.6177 \\
1.6311 \\
1.6446\end{array}$ & $\begin{array}{ll}17 & 391 \\
17 & 241 \\
17 & 094 \\
16 & 949 \\
16 & 806\end{array}$ & $\begin{array}{l}4.811 \\
4.768 \\
4.726 . \\
4.685 \\
4.644\end{array}$ \\
\hline $\begin{array}{l}6000 \\
6050 \\
6100 \\
6150 \\
6200\end{array}$ & $\begin{array}{l}2763.31 \\
2762.65 \\
2762.02 \\
2761.40 \\
2760.80\end{array}$ & $\begin{array}{l}1.6580 \\
1.6714 \\
1.6848 \\
1.6983 \\
1.7117\end{array}$ & $\begin{array}{ll}16 & 666 \\
16 & 528 \\
16 & 393 \\
16 & 260 \\
16 & 129\end{array}$ & $\begin{array}{l}4.604 \\
4.565 \\
4.527 \\
4.4 \varepsilon 9 \\
4.452\end{array}$ \\
\hline $\begin{array}{l}6250 \\
6300 \\
6350 \\
6400 \\
6450\end{array}$ & $\begin{array}{l}2760.22 \\
2759.65 \\
2759.09 \\
2758.55 \\
2758.02\end{array}$ & $\begin{array}{l}1.7251 \\
1.7386 \\
1.7520 \\
1.7655 \\
1.7789\end{array}$ & $\begin{array}{ll}16 & 000 \\
15 & 873 \\
15 & 748 \\
15 & 625 \\
15 & 503\end{array}$ & $\begin{array}{l}4.415 \\
4.379 \\
4.344 \\
4.309 \\
4.275\end{array}$ \\
\hline $\begin{array}{l}6500 \\
6550 \\
6600 \\
6650 \\
6700\end{array}$ & $\begin{array}{l}2757.51 \\
2757.00 \\
2756.51 \\
2756.04 \\
2755.57\end{array}$ & $\begin{array}{l}1.7924 \\
1.8058 \\
1.8193 \\
1.8328 \\
1.8462\end{array}$ & $\begin{array}{ll}15 & 384 \\
15 & 267 \\
15 & 151 \\
15 & 037 \\
14 & 925\end{array}$ & $\begin{array}{l}4.241 \\
4.208 \\
4.175 \\
4.143 \\
4.112\end{array}$ \\
\hline $\begin{array}{l}6750 \\
6800 \\
6850 \\
6900 \\
6950\end{array}$ & $\begin{array}{l}2755.11 \\
2754.67 \\
2754.23 \\
2753.81 \\
2753.39\end{array}$ & $\begin{array}{l}1.8597 \\
1.8732 \\
1.8866 \\
1.9001 \\
1.9136\end{array}$ & $\begin{array}{ll}14 & 814 \\
14 & 705 \\
14598 \\
14492 \\
14388\end{array}$ & $\begin{array}{l}4.081 \\
4.050 \\
4.020 \\
3.990 \\
3.961\end{array}$ \\
\hline $\begin{array}{l}7000 \\
7050 \\
7100 \\
7150 \\
7200\end{array}$ & $\begin{array}{l}2752.99 \\
2752.59 \\
2752.21 \\
2751.83 \\
2751.46\end{array}$ & $\begin{array}{l}1.9271 \\
1.9406 \\
1.9541 \\
1.9676 \\
1.9811\end{array}$ & $\begin{array}{ll}14 & 285 \\
14 & 184 \\
14 & 084 \\
13 & 986 \\
13 & 888\end{array}$ & $\begin{array}{l}3.932 \\
3.903 \\
3.875 \\
3.847 \\
3.820\end{array}$ \\
\hline $\begin{array}{l}7250 \\
7300 \\
7350 \\
7400 \\
7450\end{array}$ & $\begin{array}{l}2751.10 \\
2750.74 \\
2750.39 \\
2750.06 \\
2749.72\end{array}$ & $\begin{array}{l}1.9945 \\
2.0080 \\
2.0215 \\
2.0350 \\
2.0485\end{array}$ & $\begin{array}{ll}13 & 793 \\
13 & 698 \\
13 & 605 \\
13 & 513 \\
13 & 422\end{array}$ & $\begin{array}{l}3.793 \\
3.767 \\
3.741 \\
3.715 \\
3.690\end{array}$ \\
\hline $\begin{array}{l}7500 \\
7550 \\
7600 \\
7650 \\
7700\end{array}$ & $\begin{array}{l}2749.40 \\
2749.08 \\
2748.77 \\
2748.46 \\
2748.17\end{array}$ & $\begin{array}{l}2.0620 \\
2.0756 \\
2.0891 \\
2.1026 \\
2.1161\end{array}$ & $\begin{array}{ll}13 & 333 \\
13 & 245 \\
13 & 157 \\
13 & 071 \\
12 & 987\end{array}$ & $\begin{array}{l}3.665 \\
3.640 \\
3.616 \\
3.592 \\
3.568\end{array}$ \\
\hline $\begin{array}{l}7750 \\
7800 \\
7850 \\
7990 \\
7950\end{array}$ & $\begin{array}{l}2747.88 \\
2747.59 \\
2747.31 \\
2747.03 \\
2746.76\end{array}$ & $\begin{array}{l}2.1296 \\
2.1431 \\
2.1566 \\
2.1702 \\
2.1837\end{array}$ & $\begin{array}{l}12903 \\
12820 \\
12738 \\
12658 \\
12578\end{array}$ & $\begin{array}{l}3.545 \\
3.522 \\
3.499 \\
3.476 \\
3.454\end{array}$ \\
\hline $\begin{array}{l}8000 \\
8050 \\
8100 \\
8150 \\
8200\end{array}$ & $\begin{array}{l}2746.50 \\
2746.24 \\
2745.99 \\
2745.74 \\
2745.49\end{array}$ & $\begin{array}{l}2.1972 \\
2.2107 \\
2.2243 \\
2.23 .8 \\
2.2513\end{array}$ & $\begin{array}{ll}12 & 500 \\
12 & 422 \\
12 & 345 \\
12 & 269 \\
12 & 195\end{array}$ & $\begin{array}{l}3.432 \\
3.410 \\
3.389 \\
3.368 \\
3.347\end{array}$ \\
\hline $\begin{array}{l}8250 \\
8300 \\
8350 \\
8400 \\
8450\end{array}$ & $\begin{array}{l}2745.25 \\
2745.02 \\
2744.78 \\
2744.56 \\
2744.34\end{array}$ & $\begin{array}{l}2.2648 \\
2.2784 \\
2.2919 \\
2.3054 \\
2.3190\end{array}$ & $\begin{array}{ll}12 & 121 \\
12 & 048 \\
11 & 976 \\
11 & 904 \\
11 & 834\end{array}$ & $\begin{array}{l}3.326 \\
3.306 \\
3.286 \\
3.266 \\
3.246\end{array}$ \\
\hline
\end{tabular}


TABLE 5-Continued

\begin{tabular}{|c|c|c|c|c|}
\hline$\lambda$ & $(n-1) 10^{7}$ & $\underset{\text { add }}{(n \lambda-\lambda)}$ & $\frac{1}{\lambda}$ & $\underset{\text { subtract }}{\left(\frac{1}{n \lambda}-\frac{1}{\lambda}\right)}$ \\
\hline $\begin{array}{l}8500 \\
8550 \\
8600 \\
8650 \\
8700\end{array}$ & $\begin{array}{l}2744.12 \\
2743.90 \\
2743.69 \\
2743.49 \\
2743.28\end{array}$ & $\begin{array}{l}2.3325 \\
2.3460 \\
2.3596 \\
2.3731 \\
2.3867\end{array}$ & $\begin{array}{ll}11 & 764 \\
11 & 695 \\
11 & 627 \\
11 & 560 \\
11 & 494\end{array}$ & $\begin{array}{l}3.227 \\
3.208 \\
3.189 \\
3.170 \\
3.152\end{array}$ \\
\hline $\begin{array}{l}8750 \\
800 \\
8850 \\
8900 \\
8950\end{array}$ & $\begin{array}{l}2743.09 \\
2742.89 \\
2742.70 \\
2742.51 \\
2742.32\end{array}$ & $\begin{array}{l}2.4002 \\
2.4137 \\
2.4273 \\
2.408 \\
2.4544\end{array}$ & $\begin{array}{ll}11 & 428 \\
11 & 363 \\
11 & 299 \\
11 & 235 \\
11 & 173\end{array}$ & $\begin{array}{l}3.134 \\
\text { 3.116 } \\
\text { 3. } 099 \\
\text { 3. } 080 \\
\text { 3. } 063\end{array}$ \\
\hline $\begin{array}{l}9000 \\
9050 \\
9100 \\
9150 \\
9200\end{array}$ & $\begin{array}{l}2742.14 \\
2741.96 \\
2741.79 \\
2741.61 \\
2741.44\end{array}$ & $\begin{array}{l}2.4679 \\
2.4815 \\
2.4950 \\
2.5086 \\
2.5221\end{array}$ & $\begin{array}{ll}11 & 111 \\
11 & 049 \\
10 & 989 \\
10 & 928 \\
10 & 869\end{array}$ & $\begin{array}{l}3.046 \\
3.029 \\
3.012 \\
2.995 \\
2.979\end{array}$ \\
\hline $\begin{array}{l}9250 \\
9300 \\
9350 \\
9400 \\
9450\end{array}$ & $\begin{array}{l}2741.28 \\
2741.11 \\
2740.95 \\
2740.79 \\
2740.64\end{array}$ & $\begin{array}{l}2.5357 \\
2.5492 \\
2.5628 \\
2.5763 \\
2.5899\end{array}$ & $\begin{array}{l}10810 \\
100752 \\
10565 \\
10638 \\
10582\end{array}$ & $\begin{array}{l}2.963 \\
2.947 \\
2.931 \\
2.915 \\
2.899\end{array}$ \\
\hline $\begin{array}{l}9500 \\
9550 \\
9600 \\
9650 \\
9700\end{array}$ & $\begin{array}{l}2740.48 \\
2740.33 \\
2740.18 \\
2740.04 \\
2739.89\end{array}$ & $\begin{array}{l}2.6035 \\
2.6170 \\
2.6306 \\
2.6441 \\
2.6577\end{array}$ & $\begin{array}{ll}10 & 525 \\
10 & 471 \\
10 & 416 \\
10362 & 362 \\
10 & 309\end{array}$ & $\begin{array}{l}2.884 \\
2.869 \\
2.854 \\
2.839 \\
2.824\end{array}$ \\
\hline $\begin{array}{r}9750 \\
9800 \\
9850 \\
9900 \\
9950 \\
10000\end{array}$ & $\begin{array}{l}2739.75 \\
2739.61 \\
2739.47 \\
2739.34 \\
2739.20 \\
2739.07\end{array}$ & $\begin{array}{l}2.6713 \\
2.6848 \\
2.6984 \\
2.7119 \\
2.7255 \\
2.7391\end{array}$ & $\begin{array}{ll}10 & 256 \\
10 & 204 \\
10 & 152 \\
10 & 101 \\
10 & 050 \\
10 & 000\end{array}$ & $\begin{array}{l}2.809 \\
2.795 \\
2.780 \\
2.766 \\
2.752 \\
2.738\end{array}$ \\
\hline
\end{tabular}

The practical difficulties involve the relation of refractive index with density of air as depending upon pressure, temperature, and humidity, and on the necessary inattention to the dispersion of light. In practice the astronomer usually disregards all dependence of refractive index on color. This must involve errors in zenith distance observations on stars whose colors are intrinsically different and especially in observations of stars near the horizon where the short waves are largely absorbed and scattered by our atmosphere causing the stars to be represented only by longer waves. Because of these difficulties, tables of corrections for astronomical refraction are probably better determined from astronomical observations than from laboratory measures. The refraction tables which have been applied to the major portion of astronomical observations are those of Bessel founded upon the observations of Bradley and published in Tabulae Regiomontanae. In 1870 the Pulkowa tables were published under the title Tabulae Refractionium in usum speculae Pulcovensis Congestae. These are based upon the researches of Gylden ${ }^{48}$ and are supplemented 
by those of Fuss." The Pulkowa tables are founded upon a smaller refraction constant than Bessel's, and Newcomb (loc. cit.) says the most recent discussions and comparisons indicate a still greater diminution in the constant. The constants under discussion represent the white light index of refraction of air at $0^{\circ} \mathrm{C}$, $760 \mathrm{~mm}$, as follows: ${ }^{30}$

\begin{tabular}{|c|c|}
\hline Gylden. & 29232 , from Pulkowa, I $842-1849$ \\
\hline Fuss. & 29161, from Pulkowa, 1867-1869 \\
\hline Newcomb. & 29195, from Greenwich, $1877-1886$ \\
\hline Bauschinger. & 29152 , from Munchen, ISgI-1893 \\
\hline Courvoisier............... & 29180, from Heidleberg, 1900-1903 \\
\hline
\end{tabular}

Under the same conditions our observations give about 1.0002923 assuming the wave length $5560 \mathrm{~A}$ of maximum visibility for white light.

For photographic work a larger refraction constant must be used than for visual. If the photographic maximum is at $4200 \mathrm{~A}$ the refraction constant should be 1.0002968 and the photographic corrections are therefore 1.0154 larger than the visual. The ratio of these corrections has been found experimentally by Wilsingis to be I.OI 539 .

\section{OPTICAL TEMPERATURE COEFFICIENT}

If the Dale and Gladstone law, $\frac{n-1}{d}=$ constant, holds for air, the temperature coefficient of index variation should be identical with the temperature coefficient of volume change at constant pressure and any refractivity of air at temperature $t^{\circ} \mathrm{C}$ could be expressed in terms of the refractivity of air at $0^{\circ} \mathrm{C}$ by the relation

in which $a=0.00367$.

$$
(n-\mathrm{I})_{t}=\frac{(n-\mathrm{I})_{0}}{\mathrm{I}+a t}
$$

The following values of the optical temperature coefficient of air show considerable disagreement: Lorenz, 0.00367 ; Von Lang, 0.00310 ; Mascart, 0.00383 ; Benoit, 0.00367 ; and Walker, 0.00360 .

Our observations on the refractivity of air at temperatures of $0, I_{5}$, and $30^{\circ} \mathrm{C}$ show that $\alpha$ is a function of the wave length and increases rapidly as the absorption band in the ultra-violet is. approached. This is shown in Table 6 .

4 Fuss, ibid., 18, No. 4; I 863.

Winklemann. Handbuch der Physik, 6 (2). p. 534.

"Wilsing. Astronom. Nachr., 145, p. 293; iSgs. 
TABLE 6

\begin{tabular}{|c|r|}
\hline$\lambda$ & \multicolumn{1}{|c|}{$\alpha$} \\
\hline 8500 & 0.003672 \\
7500 & 3674 \\
6500 & 3678 \\
5500 & 3685 \\
4500 & 3700 \\
3500 & 3738 \\
2500 & 3872 \\
\hline
\end{tabular}

A decrease in the density of air due to an increase in its temperature either apparently or actually changes the position of the ultra-violet absorption band. As the temperature of the air rises the absorption and dispersion of short waves of light diminish and this effect is probably explained by the increased kinetic energy of the gas molecules rather than by the decreased density of the gas. It would be interesting to test this by ultra-violet dispersion measurements of air with density reductions at constant temperature.

Within the range of our observations the refractivity of air at any temperature for any particular wave length $\lambda$ can be obtained from measurements on air at $0^{\circ} \mathrm{C}$ by the relation mentioned above if a correction be applied to $\alpha$ which is a function of $\lambda$. A very simple correction to $\alpha$ is contained in the expression

$$
(n-I)_{t}=\frac{(n-I)_{0}}{I+t\left(\frac{\left.\alpha+3 \times 10^{6}\right)}{\lambda^{3}}\right.}
$$

in which $\alpha=0.00367$; which allows the calculation of $(n-I)_{t}$ within the limits of probable error of observation.

\section{DISPERSION FORMULAS}

A large amount of theoretical work on refraction and dispersion of transparent materials has been done in the past, and various theories have been tested by measurements of indices of refraction of solids and liquids over a wide range of spectrum from the ultraviolet through the visible and far out into the infra-red. It is especially important for this purpose to measure indices of refraction in the neighborhood of absorption bands. Measurements of refractivities of gases have heretofore been confined to a comparatively small portion of the spectrum, and although more work has been done with air than with other gases the review of previous 
work showed how incomplete it was. It was hoped that the.present investigation of the dispersion of air for red and infra-red light would give an indication of an absorption band in the infrared so that the Sellmeier or Ketteler-Helmholtz dispersion formula could be tested in its representation of the observations. The empirical Cauchy equation with three constants was first used to represent the measurements, and although the representation was quite satisfactory, there seemed to be a slight deviation in the red which might be explained by an absorption band in the infrared. An effort was made to locate such a band from our dispersion measurements, but without success.

Water vapor has a very complicated absorption spectrum in the infra-red, but dry air is known to be quite transparent to long waves. The only constituent of air which seems to absorb much infra-red light is carbon dioxide. Although carbon dioxide constitutes only 0.03 per cent of the volume of ordinary air, the absorption is quite marked for wave lengths $42700 \mathrm{~A}^{52,53}$ and $147000 A^{54}$ when these waves are received through several meters of air. Rubens and Wartenburg ${ }^{55}$ have found dry air to be quite transparent for wave lengths $230000 \mathrm{~A}, 520000 \mathrm{~A}$, I $100000 \mathrm{~A}$, and $3140000 \mathrm{~A}$. The absorption bands due to the carbon dioxide in the air are narrow and weak compared to the absorption band of air for ultra-violet light and it seems doubtful that they can exert any marked influence on dispersion. The effect of these bands is probably similar to that of the $A$ band due to atmospheric oxygen which strongly absorbs light of wave length $7600 \mathrm{~A}$, but relatively small thicknesses of air freely transmit these waves.

Koch ${ }^{56}$ measured the index of refraction of air as 1.00028806 for residual rays from gypsum $(\lambda=67094 \mathrm{~A})$ and $\mathrm{r} .00028875$ for residual rays from calcite $(\lambda=86784 \mathrm{~A})$. If no absorption band exists between $9000 \mathrm{~A}$ and $67000 \mathrm{~A}$, and if it is permissible to extrapolate the formula representing our observations, we obtain $n=1.00028 ; 6$ for the longest waves.

It is probably necessary, therefore, to conclude that if there is any marked absorption of infra-red waves by air, the band of absorption must lie at extremely long waves.

Moreover, the electromagnetic theory has connected the index of refraction $n$ of a medium to its dielectric constant $D$ by the

\footnotetext{
18 Paschen, Wied. Ann., 53, p. 334; 1894.

w Statescu, Phil. Mag., 30, p. 737; 1915.

" Rubens, Wied. Ann., 64, p. 584; 2898 .

* Rubens and Wartenburg. Phys. Zeitschr., 12. D. x080; 1911.

* Koch, Nova Acta Soc. Upsal (4), 2; 1909.
} 
relation $n^{2}=D$. This relation was derived for long waves and is not generally satisfied in the visible spectrum where all substances have more or less dispersion. For certain gases, such as hydrogen, nitrogen, and dry air, which show only small dispersion and no strong absorption in the infra-red, $n^{2}=D$ approximately, even when $n$ is taken for waves in the visible spectrum. ${ }^{57}$ For example, ${ }^{58} D$ for dry air is 1.000590 and $n^{2}$ for sodium light is I.000584. The dispersion for such substances is well represented by the simple empirical formula of Cauchy

$$
n=a+\frac{b}{\lambda^{2}}+\frac{c}{\lambda^{4}}
$$

If $n^{2}$ is not equal to $D$ for visible rays, the dispersion can not be represented by Cauchy's formula, but the Sellmeier or Ketteler-Helmholtz formula which takes into account the free periods corresponding to absorption bands of wave length $\lambda_{\kappa}$ must be used. Neglecting absorption for wave lengths $\lambda$ this formula is generally written as follows:

$$
n^{2}=\mathrm{I}+\Sigma_{\lambda^{2}-\lambda_{\kappa}^{2}}
$$

The effect on $n$ of each species of ions $K$ is represented by a term in the sum $\Sigma$ in which $m_{\kappa}$ is the dielectric constant of the $K$ ions. Then $\mathrm{I}+\Sigma m_{\kappa}$ is the observed dielectric constant $D$ of the substance for infinitely long waves. If there are two families of resonance ions, one producing the ultra-violet absorption band of wave length $\lambda_{v}$ and the other responsible for the infra-red absorption band of wave length $\lambda_{r}$, the dispersion is represented by

$$
n^{2}=\mathrm{I}+\frac{m_{\mathrm{v}} \lambda^{2}}{\lambda^{2}-\lambda_{\mathrm{v}}^{2}}+\frac{m_{\mathrm{r}} \lambda^{2}}{\lambda^{2}-\lambda_{\mathrm{r}}^{2}}
$$

Miss Howell ${ }^{59}$ gave a Sellmeier formula for air having an infrared absorption band of wave length $3 \mathrm{I} 800 \mathrm{~A}$, "probably due to traces of water vapor," but this seems very doubtful.

If there is only one family of resonance ions, the formula reduces to

$$
n^{2}=\mathrm{I}+\frac{m_{\mathrm{v}} \lambda^{2}}{\lambda^{2}-\lambda_{\mathrm{v}}^{2}}
$$


and this first term of Sellmeier's formula gives a satisfactory representation of the dispersion of all transparent substances in which the infra-red absorption is negligible.

The observational equations previously described were solved by the method of least squares and gave the following expression for the dispersion of air at $o^{\circ} \mathrm{C}$ and $760 \mathrm{~mm}$

$$
n^{2}=\mathrm{I}+\frac{0.00057378 \lambda^{2}}{\lambda^{2}-595,260}
$$

This simple Sellmeier dispersion formula represents the observations nearly as well as the Cauchy formula given above.

\section{SUMMARY}

A survey of previous researches on refraction of air shows that many investigators have worked either with white light or with one monochromatic radiation, and dispersion measurements have been limited to a small interval of the spectrum. No index measurements exist for waves longer than those corresponding to orange light, and in the ultra-violet the dispersion formulae disagree by more than 10 per cent of the refractivity.

Recent work in spectroscopy makes it very desirable to have more accurate and extensive data on the index of refraction and dispersion of air. The international system of standard wave lengths expresses the lengths of waves in air at $15^{\circ} \mathrm{C}$ and $760 \mathrm{~mm}$, and all wave-length measurements made under other conditions require small corrections because of the effect of temperature and pressure of the air upon its optical dispersion. Furthermore, it is often desirable to multiply wave lengths measured in air by the indices of refraction of air for these wave lengths and thus convert them to their value in a vacuum. An accuracy of one part in several millions is now striven for in the measurement of wave lengths, and to maintain their relative accuracy in the values reduced to vacuum it is necessary to know the indices of refraction within a few units in the seventh decimal place.

For several years this Bureau has been engaged in the accurate measurement of wave lengths. Interferometer comparisons of standard wave lengths have been made throughout a large range of spectrum and the grating spectra of more than 50 of the chemical elements have been photographed and measured in the red and infra-red spectral regions. In connection with these accu- 
rate measurements of wave lengths it was thought advisable to measure the absolute indices of refraction of air for the entire spectral region which is accessible to photography.

Accuracy and efficiency recommended the use of the Fabry and Perot interferometer for this work, since this apparatus can be conveniently inclosed in a chamber in which the temperature and pressure of the air can be regulated as desired, and it also permits simultaneous observations for a large number of different wave lengths. Sections of the circular fringes, produced by various radiations from a source of light illuminating the parallel plates of the interferometer, were photographed either with a grating or a rock-salt prism spectrograph, first when the space between the plates was evacuated, and then when dry air at measured temperature and pressure was present.

The index of refraction for a particular wave length was obtained directly from measurements of the photogiaphed interference fringes which allowed the ratio of lengths of this wave in vacuum and in air to be calculated. Observations were made at spectrum intervals of about $40 \mathrm{~A}$ from the extreme ultra-violet at $2200 \mathrm{~A}$, through the visible spectrum and in the infra-red to $9000 \mathrm{~A}$.

Complete sets of observations were made on dry air at atmospheric pressure and at temperatures of 0,15 , and $30^{\circ} \mathrm{C}$. These are quite closely represented by the following dispersion formulas of the Cauchy form:

$$
\begin{aligned}
& (n-\mathrm{I})_{0} \times \mathrm{IO}^{7}=2875.66+\frac{\mathrm{I} 3.4 \mathrm{I} 2}{\lambda^{2} \times 10^{-8}}+\frac{0.3777}{\lambda^{4} \times 10^{-16}} \\
& (n-\mathrm{I})_{15} \times 1 \mathrm{IO}^{7}=2726.43+\frac{\mathrm{I} 2.288}{\lambda^{2} \times 1 \mathrm{O}^{-8}}+\frac{0.3555}{\lambda^{4} \times 1 \mathrm{O}^{-16}} \\
& (n-\mathrm{I})_{30} \times 1 \mathrm{IO}^{7}=2589.72+\frac{\mathrm{I} 2.259}{\lambda^{2} \times 1 \mathrm{O}^{-8}}+\frac{0.2576}{\lambda^{4} \times 10^{-16}}
\end{aligned}
$$

These observations are used in the construction of a table giving the corrections which must be applied to wave lengths measured in air whose density is not normal. A table of corrections to convert wave lengths or frequencies measured in air to their values in a vacuum is also given.

The coefficient of index variation with temperature was found from these measurements to be a function of the wave length. For long waves this optical temperature coefficient is identical with the density temperature coefficient - that is, $\frac{1}{273}$-but as the 
ultra-violet absorption band is approached it increased rapidly, becoming $\frac{1}{258}$ at $2500 \mathrm{~A}$.

There seems to be no definite evidence of any strong absorption of infra-red light by dry air and it is, therefore, possible to represent the optical dispersion of air by the first term of Sellmeier's formula quite satisfactorily.

WASHINGTON, March I3, I9IS. 